\title{
Acid-inducible proton influx currents in the plasma membrane of murine osteoclast-like cells
}

Miyuki Kuno, Guangshuai Li, Yoshie Moriura, Yoshiko Hino, Junko Kawawaki and Hiromu Sakai

\begin{tabular}{|c|c|}
\hline Citation & Pflügers Archiv - European Journal of Physiology, 468(5): 837-847 \\
\hline Issue Date & $2016-5$ \\
\hline Type & Journal Article \\
\hline Textversion & author \\
\hline Rights & $\begin{array}{l}\text { This is a post-peer-review, pre-copyedit version of an article published in Pflügers } \\
\text { Archiv - European Journal of Physiology. The final authenticated version is available } \\
\text { online at: } \underline{\text { https://doi.org/10.1007/s00424-016-1796-7 }} . \\
\text { Please cite only the published version. } \\
\text { 引用の際には出版社版をご確認ご利用ください。 }\end{array}$ \\
\hline DOI & $10.1007 / \mathrm{s} 00424-016-1796^{-7}$ \\
\hline
\end{tabular}

\author{
Self-Archiving by Author(s) \\ Placed on: Osaka City University
}

Kuno, M., Li, G., Moriura, Y. et al. Acid-inducible proton influx currents in the plasma membrane of murine osteoclast-like cells. Pflügers Archiv - European Journal of Physiology, 468, 837-847 (2016). https://doi.org/10.1007/s00424-016-1796-7 


\title{
Acid-inducible proton influx currents in the plasma membrane of murine osteoclast-like cells
}

\author{
Miyuki Kuno ${ }^{1}$, Guangshuai Li $^{1}$, Yoshie Moriura ${ }^{1}$, Yoshiko Hino ${ }^{1}$, Junko Kawawaki ${ }^{2}$, \\ and Hiromu Sakai ${ }^{1}$
}

Department of Physiology ${ }^{1}$ and Central Laboratory ${ }^{2}$, Osaka City University Graduate School of Medicine, Abeno-ku, Osaka 545-8585, Japan.

Headings: Acid-inducible proton leak currents in osteoclasts

Please address correspondence to:

Dr. Miyuki Kuno

Department of Physiology

Osaka City University Graduate School of Medicine

1-4-3 Asahimachi, Abeno-ku, Osaka 545-8585

Tel: 81-06-6645-3711 Fax: 81-06-6645-3712

e-mail: kunomyk@med.osaka-cu.ac.jp

Acknowledgments: We thank Dr. Charles Edwards for critically reading the manuscript. This work was supported by a Grant-in-Aid for Scientific Research from The Ministry of Education, Science and Culture, Japan. The authors declare no competing financial interests. 


\begin{abstract}
Acidification of the resorption pits, which is essential for dissolving bone, is produced by secretion of protons through vacuolar $\mathrm{H}^{+}$-ATPases in the plasma membrane of bone-resorbing cells, osteoclasts. Consequently osteoclasts face highly acidic extracellular environments, where the $\mathrm{pH}$ gradient across the plasma membrane could generate a force driving protons into the cells. Proton influx mechanisms during the acid exposure are largely unknown, however. In this study, we investigated extracellular acid-inducible proton influx currents in osteoclast-like cells derived from a macrophage cell line
\end{abstract} (RAW264). Decreasing extracellular $\mathrm{pH}$ to $<5.5$ induced non-ohmic inward currents. The reversal potentials depended on the $\mathrm{pH}$ gradients across the membrane, and were independent of concentrations of $\mathrm{Na}^{+}, \mathrm{Cl}^{-}$and $\mathrm{HCO}_{3}{ }^{-}$, suggesting that they were carried largely by protons. The acid-inducible proton influx currents were not inhibited by amiloride, a widely-used blocker for cation channels/transporters, or by DIDS which blocks anion channels/transporters. Additionally, the currents were not significantly affected by V-ATPase inhibitors, bafilomycin $\mathrm{A}_{1}$ and N,N'-dicyclohexylcarbodiimide. Extracellular $\mathrm{Ca}^{2+}(10 \mathrm{mM})$ did not affect the currents, but $1 \mathrm{mM} \mathrm{ZnCl}_{2}$ decreased the currents partially. The intracellular $\mathrm{pH}$ in the vicinity of the plasma membrane was dropped by the acid-inducible $\mathrm{H}^{+}$influx currents, which caused overshoot of the voltage-gated $\mathrm{H}^{+}$channels after removal of acids. The $\mathrm{H}^{+}$influx currents were smaller in undifferentiated, mononuclear RAW cells and were negligible in COS7 cells. These data suggest that the acid-inducible $\mathrm{H}^{+}$-influx $\left(\mathrm{H}^{+}\right.$-leak) pathway may be an additional mechanism modifying the $\mathrm{pH}$ environments of osteoclasts upon exposure to strong acids.

Key words: extracellular acidification, proton leak, proton influx current, osteoclast 


\section{Introduction}

Osteoclasts dissolve bone tissue by acids and proteolytic enzymes which are secreted across the plasma membrane facing bone tissue (the ruffled membrane) into the resorption pit. As the ruffled membranes are rich in vacuolar-type $\mathrm{H}^{+}$-ATPases (V-ATPase), osteoclasts could transfer protons uphill against the electrochemical gradient by using energy produced by ATP hydrolysis. The resorption pit is reported to be acidified to $6.8-4.7$ [23], and acidification is required to activate lysosomal enzymes (the optimum $\mathrm{pH}=3 \sim 5$ ) and to degrade hydroxyapatite. Consequently, the ruffled membranes are exposed to extremely acidic extracellular environments. Under these conditions, the proton secretion through V-ATPases must decrease [18], and excess extracellular protons may enter the cells passively because of the large transmembrane concentration gradient for protons. However, the proton influx (proton-leak) mechanisms are largely unknown.

Some hints as to the mechanisms underlying the proton fluxes in response to the large $\mathrm{pH}$ gradients arise from the findings in intracellular acidic vesicles, such as phagosomes or lysosomes, the lumens of which are highly acidic $(\mathrm{pH}<5.5)$. In the steady state this is achieved by balancing the rates of proton pumping in by V-ATPases and passive proton leak $[4,24,26]$. Counter-ion conductances also contribute to the compensation of intravesicular charges generated by proton uptake. As the ruffled membranes are formed by exocytic fusion of lysosomes/endosomes [25], the two membranes may share common proton flux mechanisms, at least in part. It is known that the ruffled membranes possess V-ATPases and counter ion $\left(\mathrm{Cl}^{-}\right)$conductances. However, passive proton leak mechanisms activated by acidification as strong as that of acidic vesicles have not been reported. If present, the "proton-leak" may be an additional mechanism which could modify the $\mathrm{pH}$ environments of osteoclasts.

This study investigated the extracellular acid-inducible $\mathrm{H}^{+}$influx pathways in plasma membranes exposed to highly acidic environments in osteoclast-like cells derived from RAW264 cells. We found that $\mathrm{H}^{+}$influx currents were activated by an extracellular $\mathrm{pH}\left(\mathrm{pH}_{\mathrm{o}}\right)$ lower than 5.5. The ambient $\mathrm{pH}$ might be 
regulated by balancing transmembrane proton fluxes in opposite directions, the pumping out of $\mathrm{H}^{+}$and the proton influx. The present study provided evidence that the acid-inducible $\mathrm{H}^{+}$influx pathway was present in the plasma membrane of osteoclasts, suggesting that it may work as a passive $\mathrm{H}^{+}$-leak mechanism when the extracellular space is highly acidified. 


\section{Materials and methods}

Cells. Osteoclasts were generated from a mouse macrophage cell line (RAW264 cells) (Riken Cell Bank, Tsukuba, Japan) in the presence of a soluble form of receptor activator of nuclear factor $\kappa \mathrm{B}$ ligand (sRANKL) (Peprotec EC Ltd; R \& D), as described before [18-20]. RAW264 cells were maintained in the Dulbecco's modified MEM containing $100 \mathrm{U} \mathrm{ml}^{-1}$ penicillin, $0.1 \mathrm{mg} \mathrm{ml}^{-1}$ streptomycin, and $10 \% \mathrm{FCS}$ at $37^{\circ} \mathrm{C}$ in a $95 \%$ air- $5 \% \mathrm{CO}_{2}$ atmosphere. Treatment with $10-50 \mathrm{ng} \mathrm{ml}^{-1}$ of sRANKL in $\alpha$-MEM with $5-10 \%$ FCS induced differentiation of RAW264 cells into multinucleated cells. One half of the medium was changed every two or three days. Osteoclast-like cells, identified by phase-contrast microscopy and TRAP (tartate-resistant acid phosphate) activity, appeared within 4 days and were maintained for 5-16 days. Recordings were made from cells containing $\geq 3$ nuclei. The electrophysiological properties of the plasma membrane V-ATPases and voltage-gated $\mathrm{H}^{+}$channels in the RAW-derived osteoclasts share features with those in murine osteoclasts developed in primary culture [14-15, 18-20]. Some recordings were made in undifferentiated, mononuclear RAW cells, which were maintained in Dulbecco's modified MEM in the absence of sRANKL.

COS7 cells were maintained in Dulbecco's modified MEM and were used to compare the results with osteoclasts. COS7 cells lack native voltage-gated $\mathrm{H}^{+}$channels. To measure extracellular acid-induced changes in intracellular $\mathrm{pH}$, as in osteoclasts, $\mathrm{COS} 7$ cells were transfected with a bicistronic vectors carrying cDNAs for a murine $\mathrm{H}^{+}$channel (Hv1/mVSOP) and green fluorescent protein (GFP) (kindly given by Y. Okamura) by lipofectamine LTX (Invitrogen). Transformed cells (COS/Hv cells) were identified by the expression of GFP. Electrical recordings were made from GFP-positive cells 36 - 72 hrs after the transfection. $\mathrm{H}^{+}$channel currents were recorded in all these GFP-positive cells.

Electrophysiological recordings. Whole cell recordings were made as described elsewhere [14, 18-20]. Current and voltage signals were recorded with an amplifier (Axopatch 200A, Axon Instruments, Foster City, CA, USA), digitized at $4 \mathrm{kHz}$ with an analog-digital converter (Digidata 1200, Axon 
Instruments) and analyzed using pCLAMP software (Axon Instruments). The reference electrode was a $\mathrm{Ag}-\mathrm{AgCl}$ wire connected to the bath solution through a saline-agar bridge. The pipette resistances were 5-15 M $\Omega$.

For separating $\mathrm{H}^{+}$currents, the major cations and anions $\left(\mathrm{K}^{+}, \mathrm{Na}^{+}\right.$and $\left.\mathrm{Cl}^{-}\right)$in pipette and bath solutions were replaced by NMDG and aspartate, unless stated otherwise. The pipette solutions contained (in mM): 1) 120 MES, 65 NMDG-aspartate, $5 \mathrm{MgCl}_{2}, 1$ BAPTA (pH 5.5), 2) 100 HEPES, 90 NMDG-aspartate, $5 \mathrm{MgCl}_{2}, 1$ BAPTA (pH 6.5), and 3) 100 HEPES, 75 NMDG-aspartate, $5 \mathrm{MgCl}_{2}$, and 1 EGTA (pH 7.0 - 7.3). $\mathrm{Na}_{2} \mathrm{ATP}(5 \mathrm{mM})$ was added into the pipette solutions immediately before use. The extracellular solutions contained (in mM): 1) 100 HEPES, 75-90 NMDG-aspartate, $1 \mathrm{CaCl}_{2}, 1 \mathrm{MgCl}_{2}(\mathrm{pH}$ 7.3 - 6.5), 2) $100 \mathrm{MES}, 75-90$ NMDG-aspartate, $1 \mathrm{CaCl}_{2}, 1 \mathrm{MgCl}_{2}$ (pH 6.0 - 5.0), and 3) $100 \mathrm{MES}, 80-90$ NMDG, 90-95 aspartate, $1 \mathrm{CaCl}_{2}, 1 \mathrm{MgCl}_{2}, 10$ Cs-methanesulfonate (pH 4.8 - 4.0). The pH's were adjusted by $\mathrm{CsOH}$ : final concentrations of $\mathrm{Cs}^{+}$were $>10 \mathrm{mM}$. Unless stated otherwise, bath solutions contained $10 \mathrm{mM}$ glucose and 50-100 $\mathrm{MM}$ of 4,4'-diisothiocyanato-2,2'-stilbenesulfonate (DIDS), a blocker for $\mathrm{Cl}^{-}$/anion transport: the $\mathrm{Cl}^{-}$channels expressed in osteoclasts were inhibited by DIDS [7, 21-22]. Bovine serum albumin (BSA) (0.1\%) was applied in early experiments, but was removed in later experiments. The results were not affected by the presence of BSA. Most of the currents recorded under these conditions are carried by protons [14, 18-20]. In some experiments, NMDG-aspartate was replaced by tetramethylammonium (TMA)-methanesulfonate, Na-aspartate $(50 \mathrm{mM})$ or $\mathrm{NaHCO}_{3}(10 \mathrm{mM})$. In the presence of $\mathrm{Na}^{+}, 50-100 \mu \mathrm{M}$ amiloride was added to block $\mathrm{Na}^{+}-\mathrm{H}^{+}$exchangers when the $\mathrm{pH}$ of pipette solution was low $\left(\mathrm{pH}_{\mathrm{p}}\right.$ 5.5). The extracellular and intracellular $\mathrm{Cl}^{-}$concentrations were 4 and $10 \mathrm{mM}$ unless stated otherwise. To change the $\mathrm{Cl}^{-}$concentrations, NMDG-aspartate was replaced by NMDG-Cl. The $\mathrm{Cl}^{-}$-free pipette solutions were prepared by replacing $\mathrm{MgCl}_{2}$ by $\mathrm{MgSO}_{4}$. The liquid junction potentials were examined at the start and the end of the all recordings: the changes in the liquid junction potentials during recordings lasting $45-70 \mathrm{~min}$ were $8 \pm 3 \mathrm{mV}(\mathrm{n}=15)$ with the nominally $\mathrm{Cl}^{-}$-free 
pipette solutions, not significantly different from those with the solutions containing $10 \mathrm{mM} \mathrm{Cl}^{-}(4 \pm 5 \mathrm{mV}$, $\mathrm{n}=12$ ), with the same reference electrode. The osmolarities of all solutions were $280-295$ mosmol.

Voltage-steps or voltage-ramps (from -100 to $100 \mathrm{mV}$ or from -100 to $150 \mathrm{mV}: 200-250 \mathrm{mV} \mathrm{s}^{-1}$ ) were applied at holding potentials of 0 to $-80 \mathrm{mV}$ every 10-20 seconds. Capacitive currents upon voltage changes were monitored by applying voltage steps $(0 \mathrm{mV}$ for $200 \mathrm{~ms})$ preceding each voltage ramp and the offset currents during voltage ramps $\left(\mathrm{C}_{\mathrm{m}} \mathrm{x} \mathrm{dV} / \mathrm{dt}\right)$ were corrected. The whole-cell capacitance $\left(\mathrm{C}_{\mathrm{m}}\right)$ was $165 \pm 6 \mathrm{pF}(\mathrm{n}=239)$. The capacitive currents generally terminated within $50 \mathrm{~ms}$, which corresponded to the range between -100 and $-90 \mathrm{mV}$ of voltage ramps. Current amplitudes were measured after the termination of the capacitive currents. The slopes of the I-V relations for $0-50 \mathrm{mV}$ and $-90--50 \mathrm{mV}$ $\left(\right.$ Slope $_{0-50}$ and Slope -90 - -50 ) were obtained from linear fits: the latter voltage range was adjusted to exclude contamination of capacitive currents in cases where they lasted for $>50 \mathrm{~ms}$. The background leak currents were not subtracted, as they were not identified in each trace. To exclude background currents, we analyzed acid-inducible currents as the differences between before and after activation. The presence of the acid-inducible currents was detected sensitively by the changes in the slopes or the slope ratios (Slope -90 - $50_{0} / \mathrm{Slope}_{0-50}$ ) (Fig. 1c). The slope ratio was also useful in monitoring the appearance of the late currents with linear I-V relationships. Cells were exposed to acidic solutions by perfusing the recording chamber (volume, $\sim 0.8 \mathrm{ml}$ ) at a rate of about $1 \mathrm{ml} \mathrm{min}^{-1}$. The bath solutions were replaced almost completely within $\sim 1 \mathrm{~min}$. All experiments were conducted at room temperature $\left(22-26^{\circ} \mathrm{C}\right)$.

The nominal transmembrane $\mathrm{pH}$ gradients were obtained as the differences between the $\mathrm{pH}$ 's of the extracellular solutions $\left(\mathrm{pH}_{\mathrm{o}}\right)$ and the pipette solutions $\left(\mathrm{pH}_{\mathrm{p}}\right)$. Changes in the intracellular $\mathrm{pH}\left(\mathrm{pH}_{\mathrm{i}}\right)$ during exposure to acid were estimated from the reversal potentials $\left(\mathrm{V}_{\text {rev-Hv }}\right)$ of the voltage-gated $\mathrm{H}^{+}$ channels present in the plasma membranes. The $\mathrm{V}_{\text {rev-Hv}}$ 's were obtained by two methods, one from the tail current method and the other from current measurements at two different voltages $[5,10]$. In the former, tail currents were recorded at different voltages following 1-2 s long prepotentials $(40-120 \mathrm{mV})$. Leak 
currents at each voltage, estimated with short $(20 \mathrm{~ms})$ depolarization pulses which could not activate $\mathrm{H}^{+}$ channels, were subtracted. The $\mathrm{V}_{\text {rev-Hv }}$ 's were estimated as the zero-current potentials for the I-V relationships of the corrected tail currents. In the latter method, the $\mathrm{V}_{\text {rev-Hv }}$ 's were estimated from the current amplitudes at two different potentials: $\mathrm{H}^{+}$currents measured at the end of depolarization pulses $(80-140 \mathrm{mV}$ for $0.5-4 \mathrm{~s})$ and the tail currents at repolarization $(-80-0 \mathrm{mV})$ were used. The voltages and the durations were adjusted to the $\mathrm{pH}$ gradients across the membrane in each experimental condition.

Dissolution of hydroxyapatite. Hydroxyapatite particles (apamicron) were suspended in Ringer solution $\left(0.1-0.5 \mathrm{mg} \mathrm{ml}^{-1}\right)$. Absorbance of the suspensions, which were stirred continuously, was measured at $550 \mathrm{~nm}$ with the spectrophotometer in triplicate for each preparation (UV3100RL, Shimadzu, Kyoto, Japan).

Statistics. Data were expressed as means \pm s.e.m. The statistical significances $(\mathrm{p}<0.05)$ were evaluated using the unpaired Student's $t$-test.

Substances. MES and BAPTA were purchased from Dojindo Laboratories (Kumamoto, Japan) and bafilomycin $\mathrm{A}_{1}$ from Apollo Scientific (Cheshire, UK). Hydroxyapatite (apamicron) was kindly given by Sekisui Chemical Co. Ltd (Osaka, Japan). All other chemicals were obtained from Sigma (St. Louis, $\mathrm{MO}$, USA) unless specified otherwise. A concentrated stock solution of $\mathrm{Na}_{2} \mathrm{ATP}$ was prepared in $1 \mathrm{M}$ Tris-Cl. DIDS, and bafilomycin $\mathrm{A}_{1}$ were dissolved in DMSO, N,N'-dicyclohexylcarbodiimide (DCCD) in dichloromethane, and amiloride in distilled water. The final concentrations of DMSO and dichloromethane were $<0.1 \%$, which did not affect the results. 


\section{Results}

\section{Extracellular acid-induced changes in proton currents in osteoclasts}

First, we examined changes of the $\mathrm{H}^{+}$currents following extracellular acidification. When $\mathrm{Na}^{+}, \mathrm{K}^{+}$ and $\mathrm{Cl}^{-}$were replaced by $\mathrm{NMDG}^{+}$and aspartate, major contributors to the plasma membrane proton currents in osteoclasts are the V-ATPases $[18,20]$ and the voltage-gated $\mathrm{H}^{+}$channels $[14-15,19]$. Both $\mathrm{H}^{+}$ currents are generally outward, and are identified by their distinct electrophysiological and pharmacological properties. The current-voltage (I-V) relationships obtained by voltage ramps applied at a holding potential $(-80 \mathrm{mV})$ were a mixture of these $\mathrm{H}^{+}$currents. With an acidic pipette solution $\left(\mathrm{pH}_{\mathrm{p}}\right.$ 5.5), the outward $\mathrm{H}^{+}$currents were prominent at $\mathrm{pH}_{\mathrm{o}} 7.3$ (Fig. 1a) $[14,18]$ : the linear currents at $<50 \mathrm{mV}$ were mediated mostly by V-ATPases and, the outwardly rectifying currents at large depolarization, mostly by the $\mathrm{H}^{+}$channels. These outward $\mathrm{H}^{+}$currents were decreased by acidifying the extracellular medium and vanished at $\mathrm{pH}_{\mathrm{o}} \sim 5$. Further acidification $\left(\mathrm{pH}_{\mathrm{o}} 4\right)$ increased inward currents. With more alkaline pipette solutions $\left(\mathrm{pH}_{\mathrm{p}}\right.$ 7.3), the outward $\mathrm{H}^{+}$currents, particularly the $\mathrm{H}^{+}$channel currents, were small at $\mathrm{pH}_{\mathrm{o}} 7.3$ (Fig. 1b). Lowering $\mathrm{pH}_{\mathrm{o}}$ to 5.5 decreased these outward currents, and exposure to $\mathrm{pH}_{\mathrm{o}} 4.5$ increased the inward currents.

The time courses of the changes in the current amplitudes at different voltages $(-80,0$ and $+80 \mathrm{mV})$ showed that, following the reductions in the outward currents at $\mathrm{pH}_{\mathrm{o}} 5.5$, the inward currents appeared after exposure to $\mathrm{pH}_{\mathrm{o}} 4.5$ (Fig 1c, top). The slopes of the I-V relationships calculated for two voltage ranges, 0-50 $\mathrm{mV}$ (middle, closed squares; $\mathrm{S}_{0-50}$ ) and -90 - -50 mV (open squares; $\mathrm{S}_{-90}$ - -50) were slightly decreased during exposure to $\mathrm{pH}_{\mathrm{o}} 5.5$, due to decreases in the outward currents. After exposure to $\mathrm{pH}_{\mathrm{o}} 4.5$, the slopes increased with the appearance of the inward currents. It is noteworthy that the slope ratios $\left(\mathrm{S}_{-90}\right.$ ${ }_{--50} / \mathrm{S}_{0-50}$ ) also increased sharply with activation of the inward currents (Fig. 1c, bottom), indicating that the acid-induced currents were inwardly rectified. The acid-induced inward currents were also observed in the presence of $200 \mu \mathrm{M}$ DCCD, a non-specific proton pump inhibitor, which blocked the plasma 
membrane V-ATPase currents in osteoclasts completely [18] (Fig. 1d): the cell was exposed to $\mathrm{pH}_{\mathrm{o}} 4.4$ three times $\left(\mathrm{pH}_{\mathrm{p}} 7.0\right)$. The acid-induced inward currents were reversible and were activated repeatedly.

Thus strong extracellular acidification activated inward currents over a wide range of $\mathrm{pH}_{\mathrm{p}}(5.5-7.3)$. The currents recorded by applying depolarizing voltage-steps at a holding potential of $-80 \mathrm{mV}$ showed the reduction of the outward currents and the appearance of the inward currents by exposure to acid (Fig. 2a with $\mathrm{pH}_{\mathrm{p}} 5.5$ and Fig. $2 \mathrm{~b}$ with $\mathrm{pH}_{\mathrm{p}} 7.3$ ). The inward currents were also recorded by applying hyperpolarizing voltage-steps at a holding potential of $0 \mathrm{mV}\left(\mathrm{Fig} .2 \mathrm{c}\right.$ with $\mathrm{pH}_{\mathrm{p}} 6.5$ ). These acid-induced inward currents did not display time-dependent kinetics following either depolarization or hyperpolarization.

The acid-inducible inward currents were seldom observed at $\mathrm{pH}_{\mathrm{o}} \geq 6.0 . \mathrm{At}_{\mathrm{pH}} 5.5$, the acid-inducible currents were present in $\sim 20 \%$ of cells with $\mathrm{pH}_{\mathrm{p}} 7.3(\mathrm{n}=14)$ but were negligible with $\mathrm{pH}_{\mathrm{p}}$ $5.5(\mathrm{n}=23) . \mathrm{At}_{\mathrm{pH}} 4.5$, the inward currents were found in $90 \%(17 / 19)$ of cells with $\mathrm{pH}_{\mathrm{p}} 7.3,94 \%$ (17/18) with $\mathrm{pH}_{\mathrm{p}} 6.5$ and $89 \%(8 / 9)$ with $\mathrm{pH}_{\mathrm{p}} 5.5$. The amplitudes of the inward currents were measured under different $\mathrm{pH}_{\mathrm{p}}$ 's at two potentials, -80 and $0 \mathrm{mV}$ : the former fell on the part of the IV relationships representing the slope range, $\mathrm{S}_{-90--50}$, and the latter, on the part of $\mathrm{S}_{0-50}$. The mean current-densities at -80 and $0 \mathrm{mV}$, normalized by the cell capacitance, were increased by decreasing $\mathrm{pH}_{\mathrm{o}}$ (Fig. 2d). At both voltages, the inward currents appeared at $\mathrm{pH}_{\mathrm{o}}$ lower than $\sim 5.5$ over a wide range of $\mathrm{pH}_{\mathrm{p}}$ 's from 5.5 to 7.3 , suggesting that the $\mathrm{pH}_{\mathrm{o}}$, and not the $\mathrm{pH}$ gradient, was essential for activating the inward currents. The inward currents appeared when the $\mathrm{pH}_{\mathrm{o}}$ was lowered than $\sim 5.5$.

In some cells, the inward currents were followed by increases of currents in both inward and outward directions during prolonged ( $>5-10 \mathrm{~min}$ ) exposure to $\mathrm{pH}_{\mathrm{o}} \leq 4.5$, particularly in recordings with higher $\mathrm{pH}_{\mathrm{p}}(>7.0)$. These late currents had linear I-V relationships and were partially reversible after washout. In the present study, we focused on the early response, which will be designated hereafter as the acid-inducible inward current. 


\section{Acid-inducible inward currents were mediated by protons.}

The $\mathrm{V}_{\text {rev }}$ 's of the acid-inducible influx currents were obtained from the intersections of the I-V relationships before and after activation of the acid-inducible inward currents (Fig. 3a-b). The activation was confirmed from the changes in the slopes of the I-V curves. Large depolarizations, however, often destabilized recordings or activated outwardly-rectifying currents. In these cells, the slopes of the I-V relationships at greater than $50 \mathrm{mV}$ behave differently from $\mathrm{S}_{0-50}$ and $\mathrm{S}_{-90}$ - -50 (data not shown), suggesting that at large depolarizations the acid-inducible influx currents might be contaminated with the other current, possibly the acid-sensing, outwardly rectifying $\mathrm{Cl}^{-}$channels [7]. As the inhibition of the $\mathrm{Cl}^{-}$ channels by $100 \mu \mathrm{M}$ DIDS was incomplete at high voltages under $\mathrm{pH}_{\mathrm{o}} 4.5$ (by $93 \pm 3 \%$ at $\left.100 \mathrm{mV}, \mathrm{n}=4\right)$, the data with significant contamination of the outwardly rectifying currents were excluded from the estimation of the $\mathrm{V}_{\text {rev. }}$ The measured $\mathrm{V}_{\text {rev }}$ values were dependent on both $\mathrm{pH}_{\mathrm{o}}$ and $\mathrm{pH}_{\mathrm{p}}$, and were close to the equilibrium potentials for $\mathrm{H}^{+}\left(E_{H}\right)$ calculated from the Nernst equation for each $\mathrm{pH} / \mathrm{pH}$ p $($ dashed lines) (Fig. 3c). The $\mathrm{V}_{\text {rev }}$ 's were not significantly affected by DCCD, a proton pump inhibitor: $71 \pm 5 \mathrm{mV}$ $(\mathrm{n}=6)$ at $\mathrm{pH}_{\mathrm{o}} / \mathrm{pH}_{\mathrm{p}} 4.4 / 5.5$ with DCCD and $64 \pm 5 \mathrm{mV}(\mathrm{n}=4)$ without DCCD. The equilibrium potentials for $\mathrm{NMDG}^{+}$and aspartate - were $-10-+10 \mathrm{mV}$ and those for $\mathrm{Cl}^{-}$were $23 \mathrm{mV}$ for all combinations of $\mathrm{pH}_{\mathrm{o}} / \mathrm{pH}_{\mathrm{p}}$

Similar acid-inducible inward currents were observed in the presence of $\mathrm{Na}^{+}$: the currents were measured in the presence of $100 \mu \mathrm{M}$ amiloride, a blocker of the $\mathrm{Na}^{+}-\mathrm{H}^{+}$exchanger which could be activated at low intracellular $\mathrm{pH}$. When both extracellular and intracellular solutions contained $50 \mathrm{mM}$ $\mathrm{Na}^{+}$, the $\mathrm{V}_{\text {rev }}$ 's were measured from the intersections of the I-V relationships before and after activation of the acid-inducible inward currents (Fig. 3d). The $\mathrm{V}_{\text {rev }}$ was $76 \pm 6 \mathrm{mV}(\mathrm{n}=3)$ under $\mathrm{pH}_{\mathrm{o}} / \mathrm{pH}_{\mathrm{p}} 4.5 / 5.5$, which is far from $E_{N a}(0 \mathrm{mV})$, and were not affected significantly by the transmembrane concentration gradients for $\mathrm{Na}^{+}$(Fig. 3e). The solutions were nominally free of $\mathrm{HCO}_{3}{ }^{-}$. An addition of $10 \mathrm{mM} \mathrm{HCO}_{3}{ }^{-}$into both 
extracellular and intracellular solutions did not change the $V_{\text {rev }}$ 's (Fig. 3e, rightmost). These data suggested that the acid-inducible inward currents were mediated mainly by $\mathrm{H}^{+}$.

To investigate the effects of other ions on the amplitudes of the acid-inducible inward currents, the current-densities activated by exposures to $\mathrm{pH}_{\mathrm{o}} 4.5$ were measured at two potentials, 0 and $-80 \mathrm{mV}$ (Fig. 4). The acid-inducible influx currents were not affected by different combinations of extracellular and intracellular $\mathrm{Cl}^{-}$concentrations, and also by the presence of $\mathrm{Na}^{+}(50 \mathrm{mM})$ or $\mathrm{HCO}_{3}{ }^{-}(10 \mathrm{mM})$ in both solutions $\left(\mathrm{pH}_{\mathrm{p}} 7.3\right)$ (Fig. 4a). Major ions in the solutions, NMDG-aspartate, were weak bases and weak acids, which might affect the results through their proton-shuttle effects across the membranes. However, when NMDG-aspartate was replaced by TMA-methanesulfonate (strong base/strong acid), the densities of the acid $\left(\mathrm{pH}_{0} 4.5\right)$-inducible inward currents were not significantly different from those recorded with NMDG-aspartate ( $\left.\mathrm{pH}_{\mathrm{p}} 6.5\right)$ (Fig. 4b).

The acid-inducible $\mathrm{H}^{+}$-influx currents were observed in $4 / 10$ undifferentiated, mononuclear RAW cells cultured in the absence of sRANKL, and only in $1 / 10$ wild COS7 cells $\left(\mathrm{pH}_{\mathrm{o}} / \mathrm{pH}_{\mathrm{p}} 4.5 / 7.3\right)$. These incidences were lower than those of osteoclasts. Consequently, the mean current-densities in RAW cells and $\operatorname{COS} 7$ cells were significantly smaller than osteoclasts (Fig. 4c).

\section{Effects of channel/transporter modulators on the acid-inducible $\mathrm{H}^{+}$influx currents}

The effects of several widely-used channel/transporter modulators, which were reported to be effective under $\mathrm{pH}_{\mathrm{o}}$ as low as 4.5, on the acid-inducible inward currents were examined (Fig. 5a). Neither DIDS (50 -100 $\mu \mathrm{M})$, a non-specific blocker for anion channels/transporters, nor amiloride (100 $\mu \mathrm{M})$, a blocker for $\mathrm{Na}^{+}$channels (ENaC and ASIC channels) or $\mathrm{Na}^{+}-\mathrm{H}^{+}$exchangers, affected the currents at 0 and $-80 \mathrm{mV}$. The current-densities of the $\mathrm{H}^{+}$influx activated in the presence of bafilomycin $\mathrm{A}_{1}(200 \mathrm{nM})$, a selective blocker for V-ATPases or DCCD (100-200 $\mu \mathrm{M})$, a non-specific proton pump inhibitor, were not significantly different from the controls. 
Next, we examined the effects of divalent cations, calcium and zinc. There were no significant effects of $\mathrm{CaCl}_{2}(10 \mathrm{mM})$ on the current densities (Fig.5a, rightmost). The acid-inducible inward currents were not affected by $0.2 \mathrm{mM} \mathrm{ZnCl}_{2}$, but the current densities decreased slightly in the presence of $1 \mathrm{mM}$ $\mathrm{ZnCl}_{2}$ (Fig. 5b). When $1 \mathrm{mM} \mathrm{ZnCl}$ was applied after the acid-inducible $\mathrm{H}^{+}$currents appeared, the currents were decreased (Fig. 5c, upper) without apparent changes in the slope ratio (lower). The inhibition by $1 \mathrm{mM} \mathrm{ZnCl} 2$ was $14 \pm 10 \%(\mathrm{n}=3)$ with $\mathrm{pH}_{\mathrm{p}} 6.5$ and $23 \pm 7 \%(\mathrm{n}=5)$ with $\mathrm{pH}_{\mathrm{p}} 7.3$ (Fig. $\left.5 \mathrm{~d}\right)$. The inhibition seemed to be reversible, as removal of $1 \mathrm{mM} \mathrm{ZnCl}_{2}$ increased the inward currents in 6 cells: the currents were recovered to $100 \pm 4 \%$ of the amplitudes before additions of $\mathrm{ZnCl}_{2}$.

\section{Intracellular acidification induced by acid-inducible $\mathrm{H}^{+}$influx currents}

In the whole-cell configuration, the interior of the cell is buffered with high concentrations of $\mathrm{pH}$ buffers in the pipette solutions. Still, the intracellular $\mathrm{pH}$ near the plasma membrane $\left(\mathrm{pH}_{\mathrm{i}}\right)$ could be altered as a consequence of transmembrane $\mathrm{H}^{+}$fluxes $[12,19]$. We estimated the changes in the $\mathrm{pH}_{\mathrm{i}}$ during acid-exposures using the $\mathrm{V}_{\text {rev }}$ 's of voltage-gated $\mathrm{H}^{+}$channels $\left(\mathrm{V}_{\text {rev-Hv }}\right)$ (see methods) in cells exhibiting sufficient $\mathrm{H}^{+}$channel currents. The I-V relationships of the tail currents showed a shift of $\mathrm{V}_{\text {rev-Hv }}$ 's to more positive potentials by lowering $\mathrm{pH}_{\mathrm{o}}$ (Fig. 6a-b). The mean $\mathrm{V}_{\text {rev-Hv }}$ values plotted against $\mathrm{pH}_{\mathrm{o}}$ (Fig. 6c) deviated clearly from the $E_{H}$ values calculated from the nominal $\Delta \mathrm{pH}\left(\mathrm{pH}_{\mathrm{o}}-\mathrm{pH}_{\mathrm{p}}\right)($ the dotted line) at low $\mathrm{pH}_{\mathrm{o}}$ 's $(<5.5)$. The $\mathrm{pH}_{\mathrm{i}}{ }^{\prime} \mathrm{s}$ calculated as $\mathrm{pH}_{\mathrm{o}}+\mathrm{V}_{\text {rev-Hv }} / 58$ from the Nernst equation decreased steeply at $<\mathrm{pH}_{\mathrm{o}} 5.5$, for all $\mathrm{pH}_{\mathrm{p}}$ 's examined (Fig. 6d; triangles for $\mathrm{pH}_{\mathrm{p}} 5.5$, squares for $\mathrm{pH}_{\mathrm{p}} 6.5$ and circles for $\mathrm{pH}_{\mathrm{p}}$ 7.3). The decreases in $\mathrm{pH}_{\mathrm{i}}$ during acid exposures were supported by the findings that the $\mathrm{H}^{+}$channel currents showed an overshoot after removal of acids (Fig. 6e). During exposure to acids, the $\mathrm{H}^{+}$channel current amplitudes decreased and the $\mathrm{V}_{\text {rev-Hv }}$ 's, monitored continuously using current measurements at two voltages (see methods), shifted toward more positive voltages. Upon returning the $\mathrm{pH}_{\mathrm{o}}$ to 7.3 , the $\mathrm{H}^{+}$channel currents became larger and the $\mathrm{V}_{\text {rev-Hv }}$ values were lower than the controls 
(arrows). The current amplitudes ( $80-100 \mathrm{mV}$ for $0.5 \mathrm{~s}$ ) were increased to more than $200 \%$ of the controls at the maximum after washing acids $\left(\mathrm{pH}_{\mathrm{o}} 4.5\right)$ (Fig. $6 \mathrm{f}$, left). The $\mathrm{H}^{+}$channel currents decreased gradually along the recovery of $\mathrm{pH}_{\mathrm{i}}$.

We examined the changes in the $\mathrm{pH}_{\mathrm{i}}$ during acid-exposures in $\mathrm{COS} 7$ cells in which the acid-inducible inward $\mathrm{H}^{+}$currents were marginal. As wild type COS7 cells do not express native $\mathrm{H}^{+}$ channels, the cells were transfected with a murine $\mathrm{H}^{+}$channel gene (Hv1/VSOP), which enabled us to evaluate the $\mathrm{pH}_{\mathrm{i}}$ 's in $\operatorname{COS} 7$ cells from the $\mathrm{V}_{\text {rev-Hv }}$ 's. The acid-inducible $\mathrm{H}^{+}$influx currents were hardly detected in the transformed $\operatorname{COS} 7(\mathrm{COS} / \mathrm{Hv})$ cells, in none of 8 cells tested, under $\mathrm{pH}_{\mathrm{o}} / \mathrm{pH}_{\mathrm{p}} 4.5 / 6.5$. The decreases in $\mathrm{pH}_{\mathrm{i}}$ in $\mathrm{COS} / \mathrm{Hv}$ cells in the presence of extracellular acids $\left(\mathrm{pH}_{\mathrm{o}} 4.5\right.$ and 5.5) were small $\left(\mathrm{pH}_{\mathrm{p}}\right.$ 6.5) (Fig. 6d, closed squares). The overshoots of the $\mathrm{H}^{+}$channel currents upon returning the $\mathrm{pH}_{\mathrm{o}}$ from 4.5 to 7.3 were also small and transient in $\mathrm{COS} / \mathrm{Hv}$ cells (Fig. 6f).

Whether the $\mathrm{pH}_{\mathrm{i}}$ was affected by proton shuttle effects of NMDG-aspartate was also examined. At $\mathrm{pH}_{\mathrm{o}} / \mathrm{pH}_{\mathrm{p}} 7.3 / 6.5$, the $\mathrm{pH}_{\mathrm{i}}$ estimated from the $\mathrm{V}_{\text {rev-Hv }}$ was $6.75 \pm 0.05(\mathrm{n}=42)$ in the presence of NMDG/aspartate and was $6.79 \pm 0.04(\mathrm{n}=15)$ when NMDG-aspartate were replaced by TMA-methanesulfonate. Exposure to acid $\left(\mathrm{pH}_{\mathrm{o}} 4.5\right)$ decreased the $\mathrm{pH}_{\mathrm{i}}$ to $5.41 \pm 0.10(\mathrm{n}=12)$ with NMDG-aspartate and to $5.37 \pm 0.13(\mathrm{n}=9)$ with TMA-methanesulfonate. Thus the $\mathrm{pH}_{\mathrm{i}}$ 's at $\mathrm{pH}_{\mathrm{o}} 7.3$ and $\mathrm{pH}_{\mathrm{o}} 4.5$ were not significantly different between the solutions containing NMDG-aspartate and TMA-methanesulfonate, suggesting that, under the present experimental conditions, proton-shuttle effects of $\mathrm{NMDG} /$ aspartate on the acid-induced $\mathrm{pH}_{\mathrm{i}}$ changes were small if present at all.

\section{Acid-inducible $\mathrm{H}^{+}$influx currents versus V-ATPase currents.}

In the plasma membranes of osteoclasts, V-ATPases are essential to secrete protons into the extracellular space. We compared the current-densities of the acid-inducible $\mathrm{H}^{+}$influx currents $\left(\mathrm{H}^{+}\right.$-leak) with those of the $\mathrm{H}^{+}$efflux currents through the V-ATPases at different $\mathrm{pH}_{\mathrm{o}}$ 's (Fig. 7a). The V-ATPase 
currents were identified as bafilomycin $\mathrm{A}_{1}(200 \mathrm{nM})$-sensitive currents [18]. V-ATPase currents were observed over a wide range of $\mathrm{pH}_{\mathrm{o}}$ 's $(4.5-7.3)$ (open squares), while the $\mathrm{H}^{+}$-leak currents were evident only at $\mathrm{pH}_{\mathrm{o}}<\sim 5.5$ (closed squares). Depolarizations increased V-ATPase currents and decreased the $\mathrm{H}^{+}$-leak currents $\left(-80 \mathrm{mV}\right.$ in left and $0 \mathrm{mV}$ in right). The net $\mathrm{H}^{+}$currents, estimated from these $\mathrm{H}^{+}$fluxes in opposite directions, seemed to depend on $\mathrm{pH}_{\mathrm{o}}$ 's and voltages. 


\section{Discussion}

Abundant $\mathrm{H}^{+}$efflux pathways are expressed in the plasma membrane of osteoclasts, such as V-ATPases, voltage-gated $\mathrm{H}^{+}$channels, and $\mathrm{Na}^{+}-\mathrm{H}^{+}$exchangers. However, the $\mathrm{H}^{+}$influx pathways have not been investigated so far. In this study we provide evidence that exposure to strong extracellular acid $\left(<\mathrm{pH}_{\mathrm{o}} 5.5\right)$ activates an electrogenic $\mathrm{H}^{+}$influx pathway in the plasma membrane of RAW-derived osteoclasts. This acid-inducible $\mathrm{H}^{+}$influx is suggested to be a $\mathrm{H}^{+}$-leak mechanism in the plasma membranes of osteoclasts upon exposure to highly acidified extracellular environments.

Properties of the acid-inducible $\boldsymbol{H}^{+}$influx currents. The acid-inducible inward currents were characterized by a slight inward rectification and by time-independent kinetics for activation and inactivation following hyperpolarization. The $\mathrm{V}_{\text {rev }}$ 's were dependent on the $\mathrm{pH}$ gradients across the membrane, and agreed well with the theoretical $E_{\mathrm{H}}$ values. The $\mathrm{V}_{\text {rev }}$ values were not dependent on the concentrations of other ions $\left(\mathrm{NMDG}^{+}\right.$, aspartate ${ }^{-}, \mathrm{Cl}^{-}, \mathrm{Na}^{+}$and $\left.\mathrm{HCO}_{3}{ }^{-}\right)$. The current amplitudes became larger after increasing the electrochemical driving force for the $\mathrm{H}^{+}$influx, but were not affected by changes in the concentrations of either $\mathrm{Cl}^{-}, \mathrm{Na}^{+}$or $\mathrm{HCO}_{3}{ }^{-}$. Additionally, the intracellular $\mathrm{pH}$ was decreased by exposure to $\mathrm{pH}_{\mathrm{o}}<5.5$ which induced the inward currents. All these results suggest that the acid-inducible influx currents observed in the present recording conditions were largely mediated by protons.

Theoretically, it is difficult to distinguish between currents mediated by $\mathrm{H}^{+}$and $\mathrm{OH}^{-}$in the opposite directions. The inward currents were increased by decreases in $\mathrm{pH}_{0}$, which may be explained more easily by increases in the extracellular concentrations of $\mathrm{H}^{+}$rather than decreases in the extracellular concentrations of $\mathrm{OH}^{-}$. Although we cannot rule out involvement of the proton equivalents, protons are the most likely candidate for mediating the influx currents at this moment.

The $\mathrm{H}^{+}$influx currents were not induced at $\mathrm{pH}_{\mathrm{o}} \geq 6.0$ for the $\mathrm{pH}_{\mathrm{p}}$ 's ranging from 5.5 to 7.3. At $\mathrm{pH}_{\mathrm{o}}$ 5.5 , the acid-inducible currents were present in $\sim 20 \%$ of cells with $\mathrm{pH}_{\mathrm{p}} 7.3$ but were negligible with $\mathrm{pH}_{\mathrm{p}}$ 
5.5. The lower incidence at $\mathrm{pH}_{\mathrm{p}} 5.5$ might be partly due to an underestimation of the appearance because of the small amplitudes of the currents. $\mathrm{At}_{\mathrm{pH}} 4.5$, the currents were present in $\sim 90 \%$ of the cells with $\mathrm{pH}_{\mathrm{p}}$ 's ranging from 5.5 to 7.3. The activation threshold for the acid-inducible currents was thus likely to be $\mathrm{pH}_{0}<\sim 5.5$.

Effects of channel/transporter inhibitors on the acid-inducible $\mathrm{H}^{+}$influx currents. At this moment, blockers for the acid-inducible $\mathrm{H}^{+}$influx currents remain unknown. Amiloride is known as a general blocker for $\mathrm{Na}^{+}$channels including $\mathrm{ENaC}$ and ASIC channels, and for $\mathrm{Na}^{+}-\mathrm{H}^{+}$exchangers. The effectiveness of amiloride for ASIC channels under $\mathrm{pH}_{\mathrm{o}}$ as low as 4.5 was reported $[1,11]$. DIDS is a general blocker for anion channels/transporters and blocked the acid-sensitive $\mathrm{Cl}^{-}$currents in osteoclasts almost completely at $<50 \mathrm{mV}$ at $\mathrm{pH}_{0} 4.5$. The acid-inducible $\mathrm{H}^{+}$influx currents were not affected by amiloride and DIDS. We also examined the effects of extracellular divalent cations, $\mathrm{Zn}^{2+}$ and $\mathrm{Ca}^{2+}$. Neither $\mathrm{Ca}^{2+}$ (up to $10 \mathrm{mM}$ ) nor $200 \mu \mathrm{M} \mathrm{Zn}{ }^{2+}$ affected the acid-inducible $\mathrm{H}^{+}$influx currents. One $\mathrm{mM}$ $\mathrm{Zn}^{2+}$, however, decreased the acid-inducible currents partially. Higher concentrations of these divalent cations have not been tested as they often activated $\mathrm{Cl}^{-}$channels [21-22].

The proton fluxes through V-ATPases and the voltage-gated $\mathrm{H}^{+}$channels are generally one-directional, from inside to outside of the cells. Could reversed currents through these pathways mediate $\mathrm{H}^{+}$influxes during exposure to strong acids? This is an intriguing idea and might be worth investigation. The membrane sector of V-ATPases $\left(\mathrm{V}_{\mathrm{o}}\right)$ has a passive proton conductance at $\mathrm{pH} 4.2$, which is blocked by bafilomycin $\mathrm{A}_{1}$ [3]. Proton shunts (reversed currents) at $\mathrm{pH} 3.0$ have been reported in yeast V-ATPases [9]. However, in the present study, bafilomycin $\mathrm{A}_{1}$ and DCCD, proton pump blockers, did not significantly inhibit the acid-inducible $\mathrm{H}^{+}$influx currents at $\mathrm{pH}_{\mathrm{o}}$ 4.5. Also the voltage-gated $\mathrm{H}^{+}$channels did not seem to contribute to the acid-inducible $\mathrm{H}^{+}$influx currents, as the currents were not activated in COS7 cells expressing the $\mathrm{H}^{+}$channels. Thus both V-ATPases and voltage-gated $\mathrm{H}^{+}$channels are unlikely to mediate the acid-inducible $\mathrm{H}^{+}$influx currents described herein. 
The molecular identity of the acid-inducible $\mathrm{H}^{+}$influx currents is presently unknown. The plasma membrane of osteoclasts express various acid-sensing cation channels (ASIC, TRP and HCN channels) [6, $8,13,16,17]$ and acid-sensing anion channels (ClC7) [7]. However, these channels are unlikely to be responsible for the $\mathrm{H}^{+}$influx, as $\mathrm{Na}^{+}$and $\mathrm{Cl}^{-}$did not affect the currents, although their contribution to the late currents remains to be resolved. Chang et al. [2] reported inward proton currents activated by strong acids ( $\mathrm{pH} \sim 5)$ in sour taste cells. The currents are selective to protons, and are insensitive to bafilomycin $\mathrm{A}_{1}$, amiloride and DIDS. Differently from the acid-inducible currents in osteoclasts described in this study, the currents in taste cells have higher sensitivity to $\mathrm{Zn}^{2+}: 1 \mathrm{mM} \mathrm{Zn^{2+ }}$ blocks the currents nearly completely. They also do not display inward rectification. There are not sufficient data to compare these $\mathrm{H}^{+}$influx currents in more detail. It is intriguing, however, that these cells, which are exposed to strong acids, have the $\mathrm{H}^{+}$influx pathways.

Intracellular acidification by exposure to extracellular acids. We estimated the acid-induced changes in the $\mathrm{pH}_{\mathrm{i}}$ in the vicinity of the plasma membrane from the $\mathrm{V}_{\text {rev }}$ 's of co-existing voltage-gated $\mathrm{H}^{+}$ channels $\left(\mathrm{V}_{\text {rev-Hv }}{ }^{-\mathrm{H}}\right)[12,19]$. The $\mathrm{pH}_{\mathrm{i}}$ was decreased steeply by exposure to $\mathrm{pH}_{\mathrm{o}}<5.5$, near the threshold $\mathrm{pH}_{\mathrm{o}}$ for activating the $\mathrm{H}^{+}$influx currents. The $\mathrm{pH}_{\mathrm{i}}$ did not seem to be affected by the proton-shuttle with weak acid/base in solutions, as there were no significant differences between the acid-induced changes in $\mathrm{pH}_{\mathrm{i}}$ in the presence of NMDG-aspartate (weak base/acid) and those in the presence of TMA-methanesulfonate (strong base/acid). In COS7 cells, in which acid-exposures hardly induced the acid-inducible $\mathrm{H}^{+}$influx currents, the $\mathrm{pH}_{\mathrm{i}}$ decreases were small. These results suggested that the $\mathrm{pH}_{\mathrm{i}}$ decreases in the vicinity of the plasma membrane exposed to $\mathrm{pH}_{\mathrm{o}}<5.5$ were produced mainly by the acid-inducible $\mathrm{H}^{+}$influx currents.

It is noted that the voltage-gated $\mathrm{H}^{+}$channel currents were potentiated greatly upon removal of acids. The decreases in $\mathrm{pH}_{\mathrm{i}}$ during acid exposures shifted the $\mathrm{V}_{\text {rev-Hv }}{ }^{-H}$ 's to more negative potentials than the controls. The lowered $\mathrm{pH}_{\mathrm{i}}$ was maintained for a while after the $\mathrm{pH}_{\mathrm{o}}$ returned to the control level, which 
increased the driving force for proton efflux through the $\mathrm{H}^{+}$channels. The overshoot of the $\mathrm{H}^{+}$channels was small and transient in $\mathrm{COS} 7 / \mathrm{Hv}$ cells. The data suggested that the voltage-gated $\mathrm{H}^{+}$channels might contribute to reverse the intracellular acidification after the removal of extracellular acids in osteoclasts.

A consequence of the $\mathrm{H}^{+}$influx must be intracellular acidification. However, the measurements of $\mathrm{pH}_{\mathrm{i}}$ 's were made in the absence of major ions $\left(\mathrm{Na}^{+}, \mathrm{K}^{+}\right.$, and $\left.\mathrm{Cl}^{-}\right)$which contribute to regulation of $\mathrm{pH}_{\mathrm{i}}$. Also there are limitations in estimating $\mathrm{pH}_{\mathrm{i}}$ using the $\mathrm{V}_{\text {rev }}{ }^{-H v}$ 's: the values indicate the $\mathrm{pH}$ nearby the $\mathrm{H}^{+}$ channels, but may not represent the mean $\mathrm{pH}_{\mathrm{i}}$ of the whole cytosol. Although the $\mathrm{H}^{+}$-influx currents could acidify osteoclasts, the net effects on $\mathrm{pH}_{\mathrm{i}}$ 's and osteoclast functions should be evaluated under more physiological conditions.

" $H^{+}$-leak" at the plasma membrane of osteoclasts. We started the present study, after being inspired by regulation mechanisms of intravesicular pH's of acidic vesicles. Intriguingly, the threshold $\mathrm{pH}_{\mathrm{o}}$ for the acid-inducible $\mathrm{H}^{+}$influx currents is close to the vesicular $\mathrm{pH}$ of phagosomes or lysosomes $(<$ 5.5). The vesicular $\mathrm{pH}$ is considered to be regulated by balancing the $\mathrm{H}^{+}$accumulation by V-ATPases and $\mathrm{H}^{+}$-leaks $[4,24,26]$. On the other hand, the $\mathrm{H}^{+}$fluxes in the plasma membranes of osteoclasts have been studied focusing on $\mathrm{H}^{+}$efflux mechanisms, that is, the proton pump (V-ATPases) activities of the plasma membrane. The present study provided evidence that the acid-inducible $\mathrm{H}^{+}$influx $\left(\mathrm{H}^{+}\right.$leak $)$mechanism is also present in the plasma membrane. Along with extracellular acidification, the $\mathrm{H}^{+}$efflux through V-ATPases decreases and the $\mathrm{H}^{+}$influx increases. Amplitudes of both currents were also voltage-dependent: the pump currents were increased and the $\mathrm{H}^{+}$leak currents were decreased by depolarization. Thus the balance between the two currents varies according to ambient $\mathrm{pH}$ and voltages and also might be affected by the cellular conditions in individual cells. Importantly, the working range of $\mathrm{pH}_{\mathrm{o}}$ was wide for the V-ATPase currents but was limited $\left(\mathrm{pH}_{\mathrm{o}}<5.5\right)$ for the $\mathrm{H}^{+}$leak currents.

Hydroxyapatite, a major component of bone minerals, was dissolved by a 3 min-exposure to $\mathrm{pH} 5.5$ only slightly ( $\sim 5 \%)$ (Fig. 7b, left). The dissolution at pH 5.5, however, became significant when the 
exposure period was prolonged (right) $(\sim 30 \%$ for $3 \mathrm{~h})$. The $\mathrm{pH}$ in the resorption pit is reported to be ranged from $4.7-6.8$ [23]. It is suggested that protons secreted by V-ATPases acidify the pit and then the $\mathrm{H}^{+}$-leak pathway will be activated when the $\mathrm{pH}_{\mathrm{o}}$ is decreased sufficiently (Fig. $7 \mathrm{c}$ ): the resultant $\mathrm{pH}_{\mathrm{o}}$ depends on the amounts of these $\mathrm{H}^{+}$fluxes in opposite directions. It is conceivable that the two-way $\mathrm{H}^{+}$ flux mechanisms, which are pumping out of protons by V-ATPases and uptake of protons by the $\mathrm{H}^{+}$-leak pathway, may have advantages in fine regulation of ambient $\mathrm{pH}$. It remains to be clarified whether the $\mathrm{H}^{+}$-leak pathway is also expressed in the ATPase-rich membranes of acidic vesicles or not. Identification of the molecular mechanism behind the acid-inducible $\mathrm{H}^{+}$currents would advance our understanding of the physiological/pathological relevance of the novel $\mathrm{H}^{+}$-leak pathway to cellular functions. 


\section{References}

1. Askwith CC, Wemmie JA, Price MP, Rokhlina T, Welsh MJ (2004) Acid-sensing ion channel 2 (ASIC2) modulates ASIC1 $\mathrm{H}^{+}$-activated currents in hippocampal neurons. $\mathrm{J}$ Biol Chem 279:18296-18305. PMID 14960591

2. Chang RB, Waters H, Liman ER (2010) A proton current drives action potentials in genetically identified sour taste cells. Proc Natl Acad Sci USA 107: 22320-22325. Doi: 10.1073/pnas.1013664107.

3. Crider BP, Xie X-S, Stone DK (1994) Bafilomycin inhibit proton flow through the $\mathrm{H}^{+}$channel of vacuolar proton pump. J Biol Chem 269:17379-17381. PMID 8021236.

4. Grabe M, Oster G (2001) Regulation of organelle acidity. J Gen Physiol 117:329-343. PMID 11279253

5. Humez S, Fournier F, Guilbault P (1995) A voltage-dependent and pH-sensitive proton current in Rana esculenta oocytes. J Memb Biol 147:207-215. PMID 8568856.

6. Jahr H, van Driel M, van Osch GJVM, Weinans H, van Leeuwen JPTM (2005) Identification of acid-sensing ion channels in bone. Biochem Biophys Res Comm 337:349-354. doi:10.1016/j.bbrc.2005.09.054

7. Kajiya H, Okamaoto F, Ohgi K, Nakao A, Fukushima H, Okabe K (2009) Characteristics of $\mathrm{ClC}^{-} \mathrm{Cl}^{-}$ channels and their inhibition in mutant (G215R) associated with autosomal dominant osteopetrosis type II in native osteoclasts and hClcn7 gene-expressing cells. Pflügers Arch 458:1049-1059. Doi: $10.1007 / \mathrm{s} 00424-009-0689-4$.

8. Kato K, Morita I (2013). Promotion of osteoclast differentiation and activation in spite of impeded osteoclast-lineage differentiation under acidosis: effects of acidosis on bone metabolism. BioSci Trends 7:33-41. Doi: 10.5582/bst.2013.v7.1.33

9. Kettner C, Bertl A, Obermeyer G, Slayman C, Bihler H (2003) Electrophysiological analysis of the 
yeast V-type proton pump: variable coupling ratio and proton shunt. Biophys J 85:3730-3738. PMID 14645064.

10. Kuno M, Ando H, Morihata H, Sakai H, Mori H, Sawada M, Oiki S (2009) Temperature dependence of proton permeation through a voltage-gated proton channel. J Gen Physiol 134:191-205. Doi: 10.1085/jgp.200910213.

11. Lingueglia E (2007) Acid-sensing ion channels in sensory perception. J Biol Chem 282:17325-17329. PMID 17430882.

12. Matsuura T, Mori T, Hasaka M, Kuno M, Kawawaki J, Nishikawa K, Narahashi T, Sawada M, Asada A (2012) Inhibition of voltage-gated proton channels by local anaesthetics in GMI-R1 rat microglia. J Physiol 590:827-843. Doi: 10.1113/jphysiol.2011.218149.

13. Mizoguchi F, Mizuno A, Hayata T, Nakashima K, Heller S, Ushida T, Sokabe M, Miyasaka N, Suzuki M, Ezura Y, Noda M (2008) Transient receptor potential vanilloid 4 deficiency suppresses unloading-induced bone loss. J Cell Physiol 216:47-53. PMID 18264976

14. Mori H, Sakai H, Morihata H, Kawawaki J, Amano H, Yamano T, Kuno M (2003) Regulatory mechanisms and physiological relevance of a voltage-gated $\mathrm{H}^{+}$channel in murine osteoclasts: phorbol myristate acetate induced cell acidosis and the channel activation. J Bone Miner Res 18:2069-2076. PMID 14606521.

15. Nordström T, Rotstein OD, Romanek R, Asotra S, Heersche JNM, Manolson MF, Brisseau GF, Grinstein S (1995) Regulation of cytoplasmic pH in osteoclasts. Contribution of proton pumps and a proton-selective conductance. J Biol Chem 270:2203-2212. PMID 7836451.

16. Notomi T, Kuno M, Ohura K, Noda M, Skerry TM (2015) Zinc-induced effects on osteoclastogenesis involve activation of hyperpolarization-activated cyclic nucleotide modulated channels via changes in membrane potential. J Bone Miner Res 30: 1618- 1626. Doi: 10.1002/jbmr.2507.

17. Rossi F, Siniscalco D, Luongo L, De Petrocellis L, Bellini G, Petrosino S, Torella M, Santoro C, 
Nobili B, Perrotta S, DiMazro V, Maione S (2009) The endovanilloid/endocannabinoid system in human osteoclasts: possible involvement in bone formation and resorption. Bone 44:476-84. PMID: 19059369

18. Sakai H, Kawawaki J, Moriura Y, Mori H, Morihata H, Kuno M (2006) pH dependence and inhibition by extracellular calcium of proton currents via plasmalemmal vacuolar-type $\mathrm{H}^{+}$-ATPase in murine osteoclasts. J Physiol 576:417-425. Doi:10.1113/physiol.2006.117176.

19. Sakai H, Li G, Hino Y, Moriura Y, Kawawaki J, Sawada M, Kuno M (2013) Increases in intracellular $\mathrm{pH}$ facilitate endocytosis and decrease availability of voltage-gated proton channels in osteoclasts and microglia. J Physiol 591:5851-5866. Doi: 10.1113/jphysiol.2013.263558.

20. Sakai H, Moriura Y, Notomi T, Kawawaki J, Ohnishi K, Kuno M (2010) Phospholipase C-dependent $\mathrm{Ca}^{2+}$-sensing pathways leading to endocytosis and inhibition of the plasma membrane vacuolar $\mathrm{H}^{+}$-ATPase in osteoclasts. Am J Physiol (Cell Physiol) 299:C570-C578. Doi: 10.1152/ajpcell.00486.2009.

21. Sakai H, Nakamura F, Kuno M (1999) Synergetic activation of outwardly rectifying $\mathrm{Cl}^{-}$currents by hypotonic stress and external $\mathrm{Ca}^{2+}$ in murine osteoclasts. J Physiol 515:157-168. PMID 9925886.

22. Sakuta K, Sakai H, Mori H, Morihata H, Kuno M (2002) $\mathrm{Na}^{+}$dependence of extracellular $\mathrm{Ca}^{2+}$-sensing mechanisms leading to activation of an outwardly rectifying $\mathrm{Cl}^{-}$channel in murine osteoclasts. Bone 31:374-380. PMID 12231409.

23. Silver IA, Murrills RJ, Etherington DJ (1988) Microelectrode studies on the acid microenvironment beneath adherent macrophages and osteoclasts. Exp Cell Res 175:266-276. PMID 3360056.

24. Steinberg BE, Touret N, Vargas-Caballero M, Grinstein S (2007) In situ measurement of the electrical potential across the phagosomal membrane using FRET and its contribution to the proton-motive force. Proc Natl Acad Sci USA 104:9523-9528. Doi: 10.1073/pnas.0700783104.

25. Toyomura T, Murata Y, Yamamoto A, Oka T, Sun-Wada GH, Wada Y, Futai M (2003) From 
lysosomes to the plasma membrane: localization of vacuolar-type $\mathrm{H}^{+}$-ATPase with the a3 isoform during osteoclast differentiation. J Biol Chem 278:22023-22030. PMID 12672822.

26. Van Dyke RW (1993) Acidification of rat liver lysosomes: quantitation and comparison with endosomes. Am J Physiol 265:C901-C917. PMID 823831. 
Figure legends

Fig. 1 Acid-induced changes in $\mathrm{H}^{+}$currents

Fig. 1
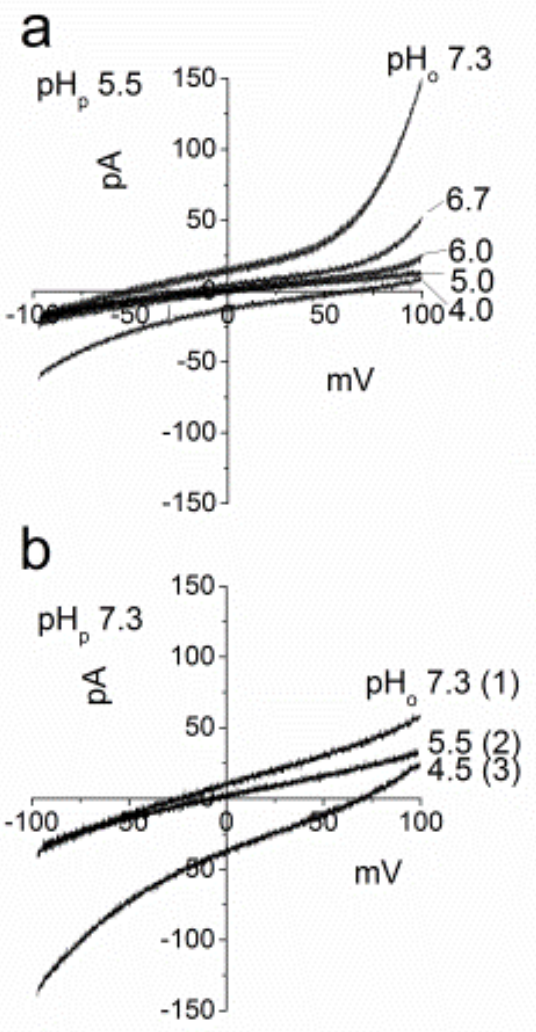

C $\quad \mathrm{pH}_{\circ}$

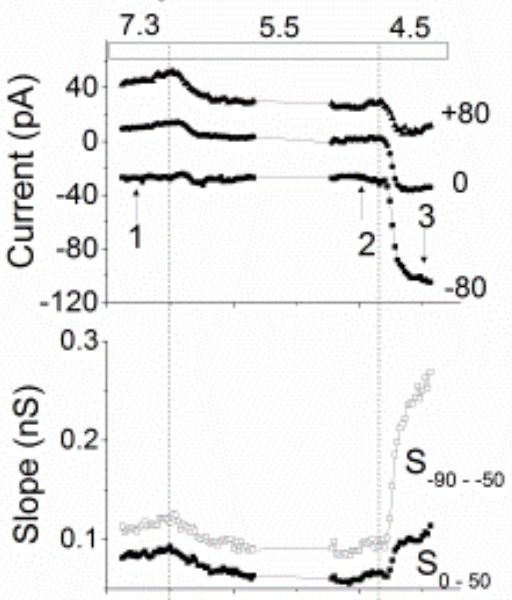

5 (2)

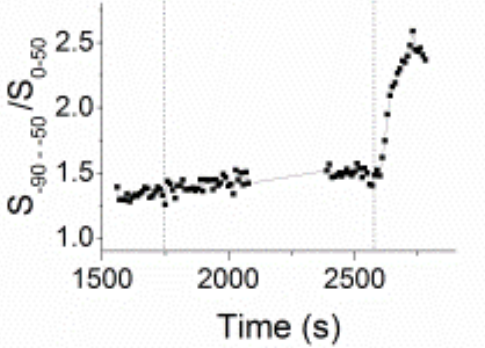

d $\mathrm{pH}_{0}$

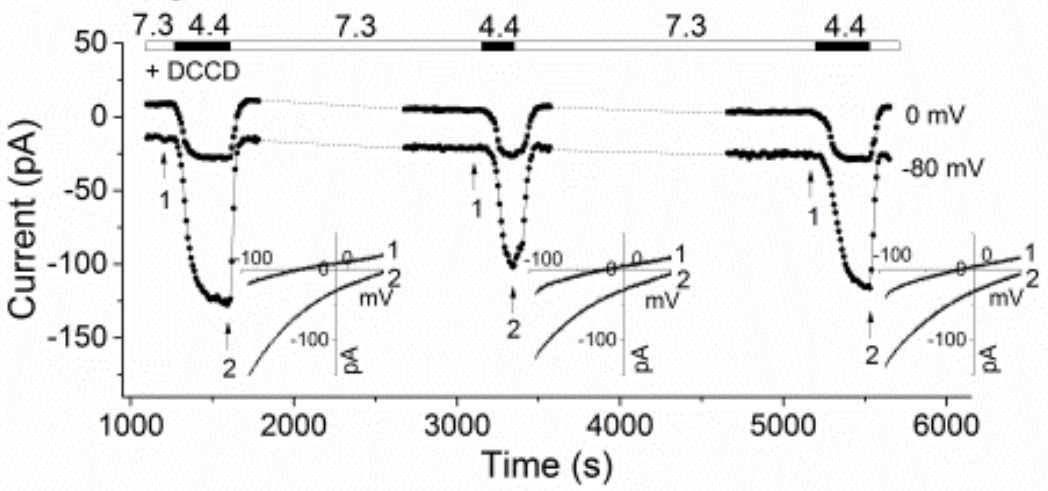


a, I-V relationships of whole-cell $\mathrm{H}^{+}$currents evoked by voltage ramps applied at a holding potential of $-80 \mathrm{mV}$. The $\mathrm{pH}_{\mathrm{o}}$ was lowered stepwise from 7.3, to $6.7,6.0,5.0$ and 4.0. The $\mathrm{pH}_{\mathrm{p}}$ was 5.5. b, I-V relationships for the currents in a cell exposed to $\mathrm{pH}_{\mathrm{o}}$ 7.3, 5.5 and 4.5. The $\mathrm{pH}_{\mathrm{p}}$ was 7.3. c, time courses of the acid inducible currents at three potentials $(-80,0$ and $+80 \mathrm{mV}$ ) (top), slopes of the I-V relationships over $-90--50 \mathrm{mV}$ (open squares, $\mathrm{S}_{-90}-{ }_{-50}$ ) and $0-50 \mathrm{mV}$ (closed squares, $\mathrm{S}_{0-50}$ ) (middle), and the slope ratio $\left(\mathrm{S}_{-90}--_{50} / \mathrm{S}_{0-50}\right)$ (bottom). The data from $\mathrm{b}$ and $\mathrm{c}$ were obtained from the same cell. The current traces in 1-3 in b were recorded at time 1-3 indicated in $\mathrm{c}$. The abscissa represents time after the whole-cell configuration was made. $\mathbf{d}$, the time courses of the changes in the current amplitudes $(0$ and $-80 \mathrm{mV})$ in the presence of $200 \mu \mathrm{M}$ DCCD, a proton pump inhibitor. The $\mathrm{pH}_{\mathrm{o}}$ was lowered from 7.3 to 4.4 repeatedly: the exposure periods were 6,3 and $5 \mathrm{~min}$ for each. The inset records represent the I-V relationships obtained at time- 1 and -2 during each trial. $\mathrm{The}_{\mathrm{pH}}$ was 7.0. 
Fig. 2 Effects of acids on the whole-cell currents

Fig.2

a

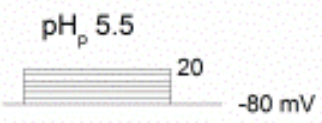

$\mathrm{pH}_{0} 7.3 \quad \mathrm{pH}_{0} 4.0$

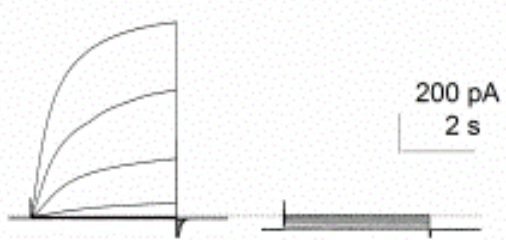

C
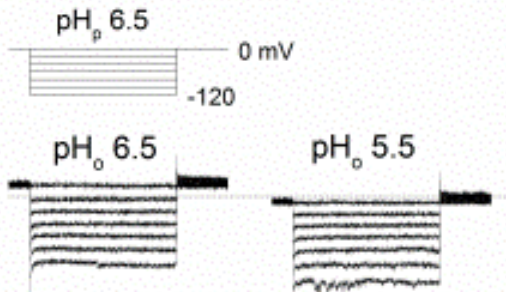

d $\quad-80 \mathrm{mV}$

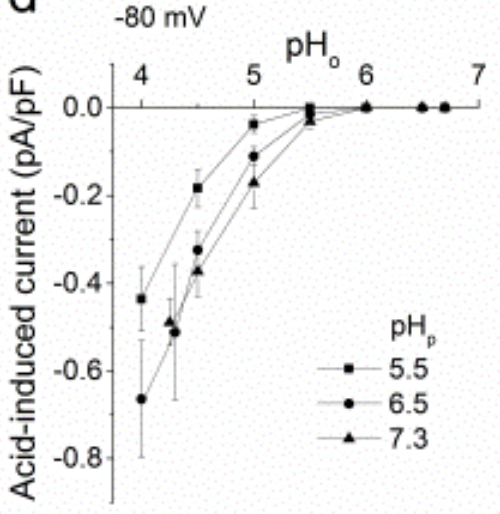

b

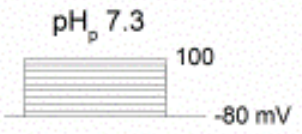

$\mathrm{pH}_{0} 7.3$

$\mathrm{pH}_{0} 4.3$

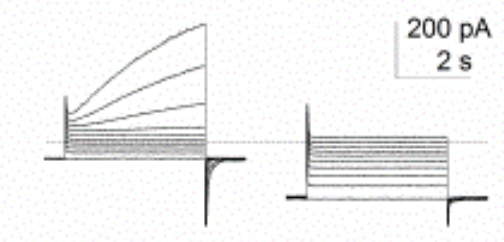

$00 \mathrm{pA}$

pA

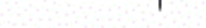


a-b, whole cell currents evoked by depolarization pulses applied at a holding potential of $-80 \mathrm{mV}$ with $\mathrm{pH}_{\mathrm{p}} 5.5$ (a) and 7.3 (b). The $\mathrm{pH}_{\mathrm{o}}$ was decreased from 7.3 to 4.0 in a and, to 4.3 in b. c, whole cell currents evoked by hyperpolarization pulses applied at a holding potential of $0 \mathrm{mV}\left(\mathrm{pH}_{\mathrm{p}}\right.$ 6.5). The $\mathrm{pH}_{\mathrm{o}}$ was decreased from 6.5 to 5.5 and 4.1, and then returned to 6.5. The dotted line indicates the zero current level. d, the densities of the acid-inducible currents under different $\mathrm{pH}_{\mathrm{p}}$ 's $(5.5,6.5$ and 7.3). The data at $-80 \mathrm{mV}$ (left) and $0 \mathrm{mV}$ (right) are plotted against $\mathrm{pH}_{\mathrm{o}}(\mathrm{n}=8-23)$. Data are means \pm sem. 
Fig. 3 The reversal potentials for the acid-inducible inward currents

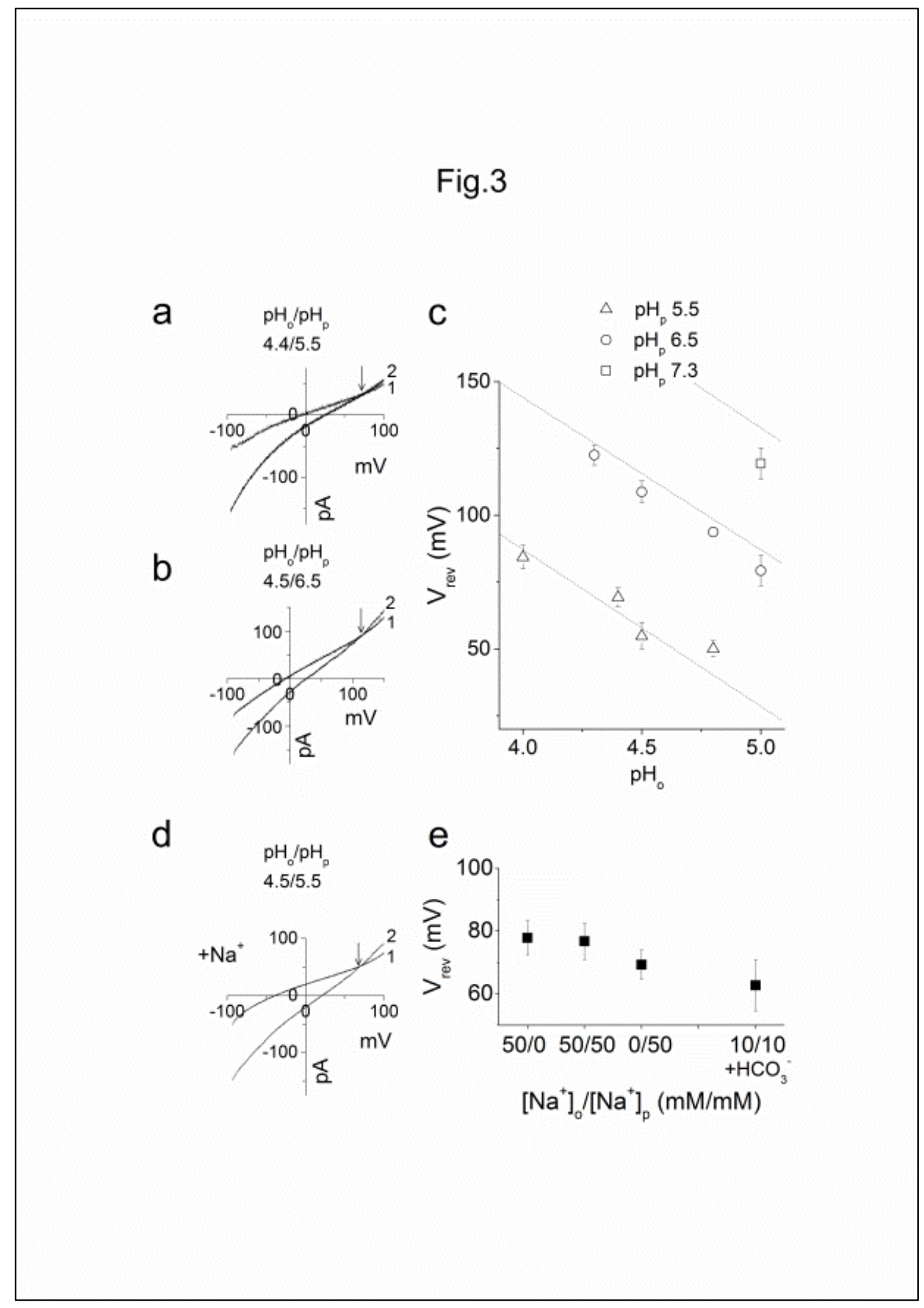


$\mathbf{a}-\mathbf{b}$, the I-V relationships before (1) and after (2) activation of the acid-induced inward currents $\left(\mathrm{pH}_{\mathrm{o}} / \mathrm{pH}_{\mathrm{p}}\right.$ 4.4/5.5 in a and 4.5/6.5 in b). Each trace is average of 2-5 recordings. The background currents were not subtracted. The voltage ramps up to $100 \mathrm{mV}$ (a) or $150 \mathrm{mV}$ (b) were applied at the holding potential (-80 $\mathrm{mV})$. Arrows indicate the reversal potentials $\left(\mathrm{V}_{\text {rev }}\right), 73 \mathrm{mV}$ for a and $114 \mathrm{mV}$ for b. $\mathbf{c}$, the $\mathrm{V}_{\text {rev }}-\mathrm{pH}_{\mathrm{o}}$ plots of the acid-inducible inward currents (triangles for $\mathrm{pH}_{\mathrm{p}} 5.5$, circles for $\mathrm{pH}_{\mathrm{p}} 6.5$ and squares for $\mathrm{pH}_{\mathrm{p}} 7.3$ ) (n $=3$ - 21). The dotted lines indicate equilibrium potentials of $\mathrm{H}^{+}$for the different $\mathrm{pH}_{\mathrm{p}}$ 's. d, the $\mathrm{I}-\mathrm{V}$ relationships recorded before (1) and after (2) activation of the acid-inducible currents in the presence of $\mathrm{Na}^{+}\left(\mathrm{pH}_{\mathrm{o}} / \mathrm{pH}_{\mathrm{p}}\right.$ 4.5/5.5). Both bath and pipette solutions contained $50 \mathrm{mM} \mathrm{Na}{ }^{+}$. The $\mathrm{V}_{\text {rev }}$ was $70 \mathrm{mV}$ (arrow). e, the $\mathrm{V}_{\text {rev }}$ 's of acid-inducible currents $\left(\mathrm{pH}_{\mathrm{o}} / \mathrm{pH}_{\mathrm{p}}\right.$ 4.5/5.5) for different transmembrane concentration gradients of $\mathrm{Na}^{+}(\mathrm{n}=3-5)$. The right most represents the $\mathrm{V}_{\text {rev }}$ 's in the presence of $10 \mathrm{mM}$ $\mathrm{NaHCO}_{3}$ in both bath and pipette solutions $(n=3)$. There was no significant difference in the $\mathrm{V}_{\text {rev }}$ 's. In $\mathrm{c}$ and e, data are means \pm sem. 
Fig. 4 Effects of ions on the amplitudes of the acid -inducible $\mathrm{H}^{+}$influx currents

Fig.4

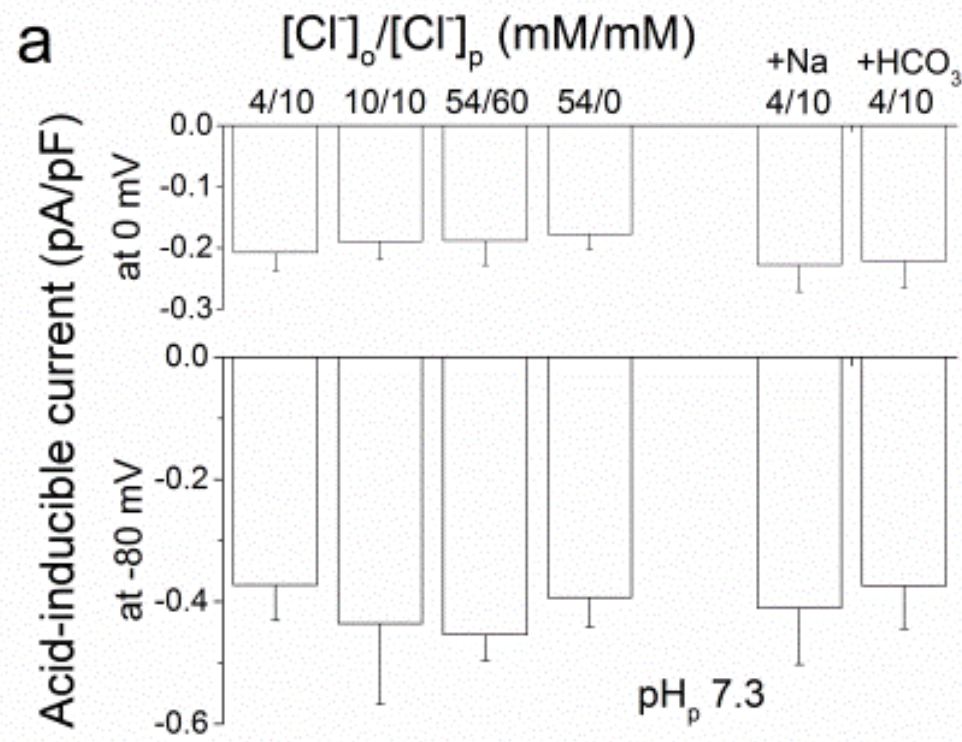

b

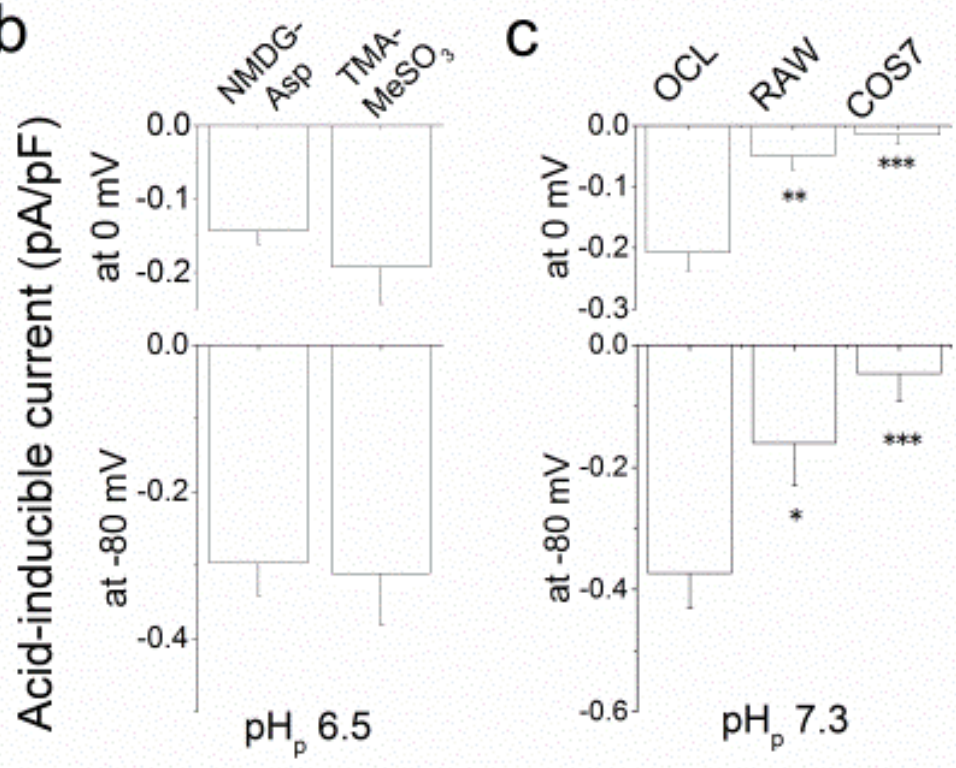


a, the current-densities at 0 and $-80 \mathrm{mV}$, in the presence of different combinations of extracellular and intracellular $\mathrm{Cl}^{-}$concentrations $\left([\mathrm{Cl}]_{\mathrm{o}} /[\mathrm{Cl}]_{\mathrm{p}}\right)($ in $\mathrm{mM})(\mathrm{n}=4-19)$. In the right columns, $50 \mathrm{mM} \mathrm{Na}^{+}$or 10 $\mathrm{mM} \mathrm{NaHCO} 3$ was present in both extracellular and intracellular solutions $(n=5) . \mathbf{b}$, the current-densities at 0 and $-80 \mathrm{mV}$ when NMDG-aspartate was replaced by TMA-methanesulfonate (TMA-MeSO${ }_{3}$ ). c, the current-densities in osteoclasts $(\mathrm{n}=19)$, undifferentiated mononuclear RAW cells $(\mathrm{n}=10)$ and in wild-type COS7 cells $(\mathrm{n}=10) .{ }^{*} \mathrm{p}<0.05,{ }^{* *} \mathrm{p}<0.005$ and ${ }^{* * *} \mathrm{p}<0.001$, compared with osteoclasts. In a-c, all solutions contained $50-100 \mu \mathrm{M}$ DIDS and the $\mathrm{pH}_{\mathrm{o}}$ was 4.5 . The $\mathrm{pH}_{\mathrm{p}}$ was 7.3 for a and $\mathrm{c}$, and 6.5 for $b$. Data are means \pm sem. 
Fig. 5 Effects of channel/transporter blockers on the acid-inducible $\mathrm{H}^{+}$currents

Fig. 5

a

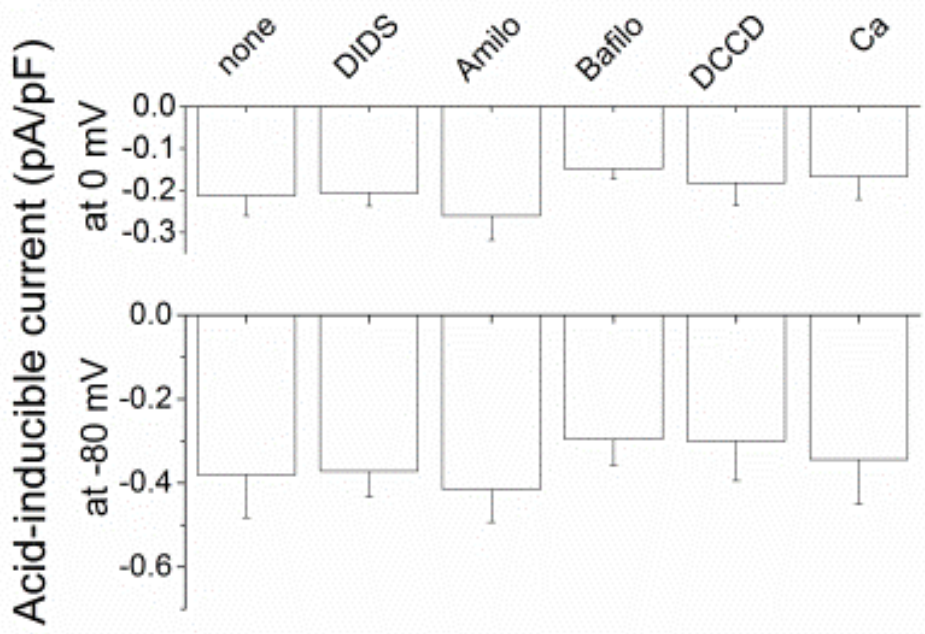

b

$\mathrm{ZnCl}_{2}$ (mM)
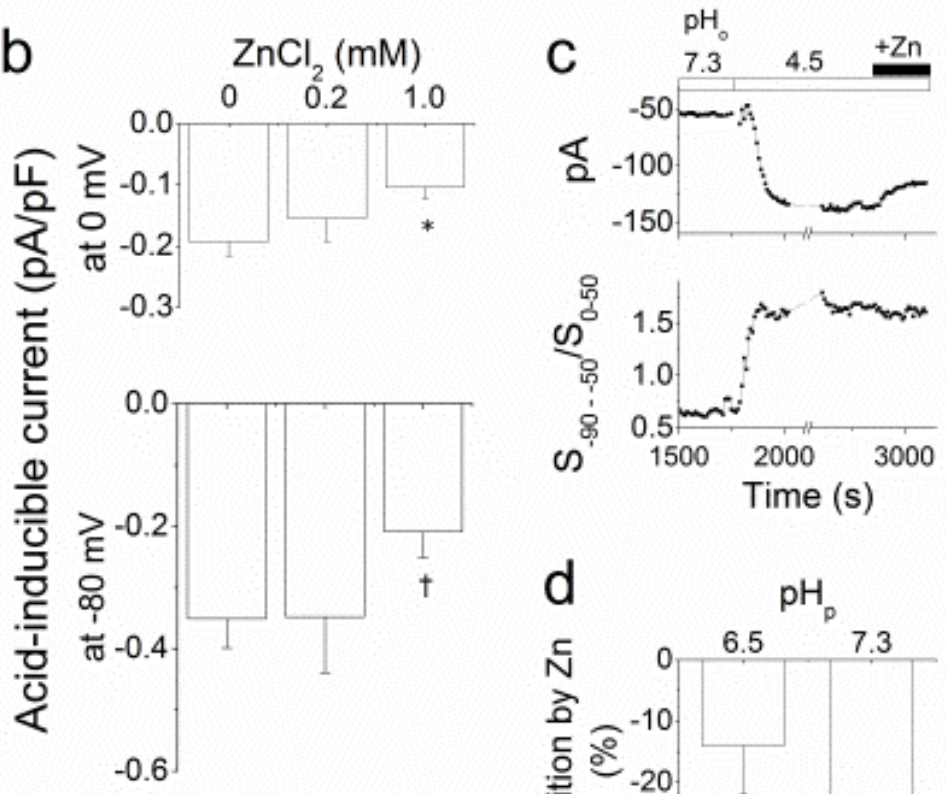

d

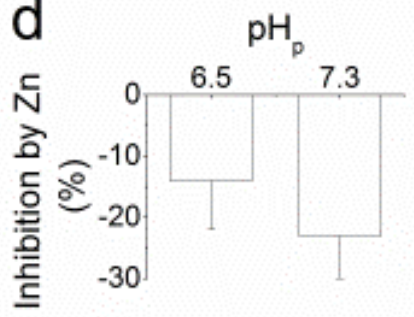


a, the current-densities of the acid $\left(\mathrm{pH}_{\mathrm{o}} 4.5\right)$-inducible $\mathrm{H}^{+}$currents at 0 and $-80 \mathrm{mV}$ under $\mathrm{pH}_{\mathrm{p}} 7.3$, in the absence of blockers (none, $n=6$ ), in the presence of 50-100 $\mu$ M DIDS $(n=18), 100 \mu M$ amiloride $(n=$ 8), $200 \mathrm{nM}$ bafilomycin $\mathrm{A}_{1}(\mathrm{n}=11), 100 \mu \mathrm{M} \operatorname{DCCD}(\mathrm{n}=6)$ and $10 \mathrm{mM} \mathrm{CaCl}_{2}(\mathrm{n}=4)$. b, the current-densities of the acid-inducible $\mathrm{H}^{+}$currents $\left(\mathrm{pH}_{\mathrm{o}} / \mathrm{pH}_{\mathrm{p}}\right.$ 4.5/7.3) activated in the presence of $0,0.2$ and $1.0 \mathrm{mM} \mathrm{ZnCl}_{2}(\mathrm{n}=12-17)$. All extracellular solutions contained $100 \mu \mathrm{M}$ DIDS. $* \mathrm{p}<0.05 . \dagger \mathrm{p}=0.06$. c, the time courses of the changes in the current amplitudes at $-80 \mathrm{mV}$ (upper) and the slope ratios of the I-V relationships (lower) of the acid-inducible $\mathrm{H}^{+}$currents $\left(\mathrm{pH}_{\mathrm{o}} / \mathrm{pH}_{\mathrm{p}} 4.5 / 6.5\right) . \mathrm{ZnCl}_{2}(1 \mathrm{mM})$ was added after the acid-inducible currents reached the steady-state. $\mathbf{d}$, the inhibition of the acid $\left(\mathrm{pH}_{\mathrm{o}} 4.5\right)$-inducible currents $(-80 \mathrm{mV})$ by $1 \mathrm{mM} \mathrm{ZnCl} 2 . \mathrm{pH}_{\mathrm{p}}$ 's were 6.5 or $7.3(\mathrm{n}=3-5)$. Data are means $\pm \mathrm{sem}$. 
Fig. 6 Extracellular acid-induced intracellular acidification

Fig. 6

a
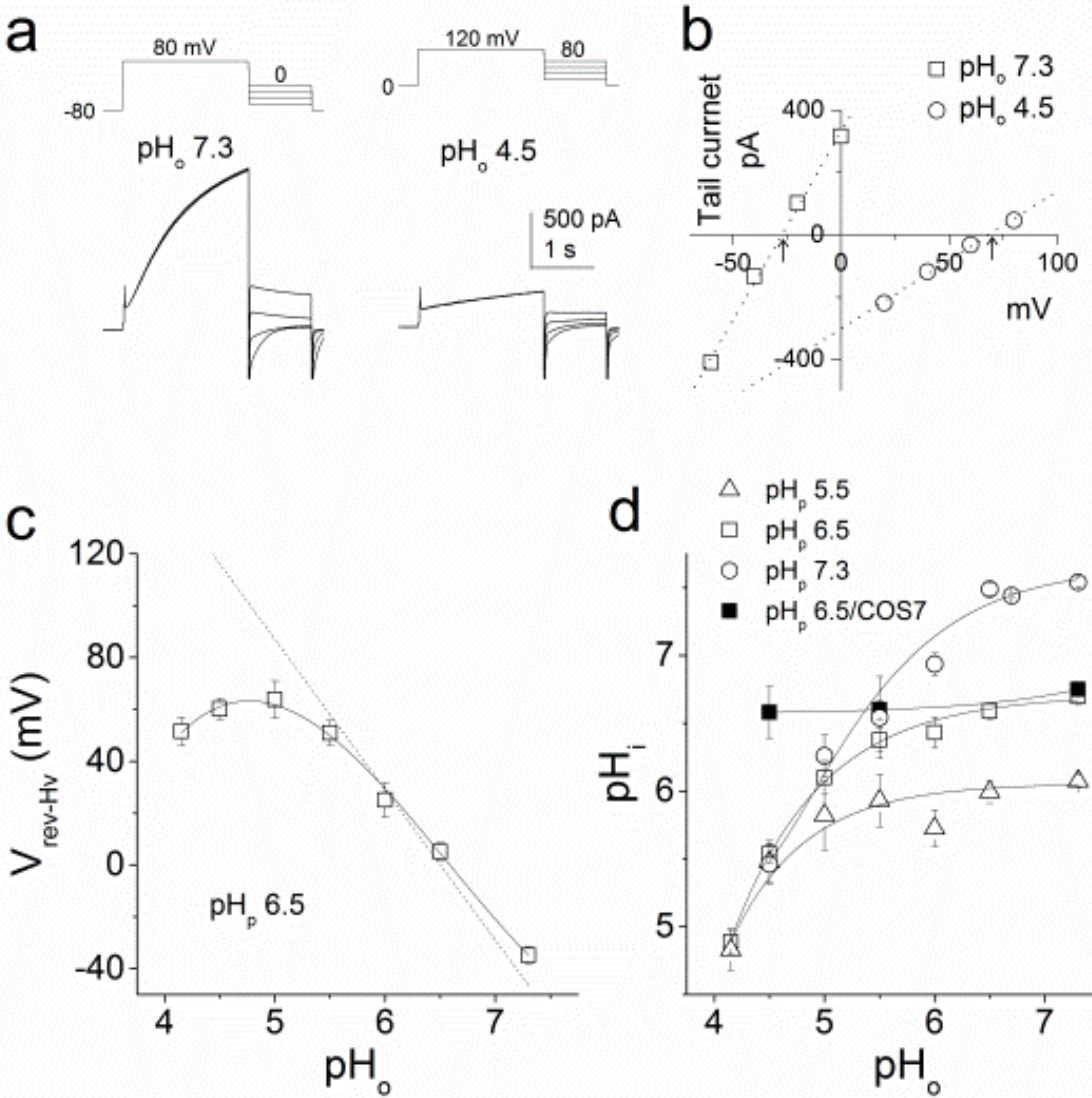

e
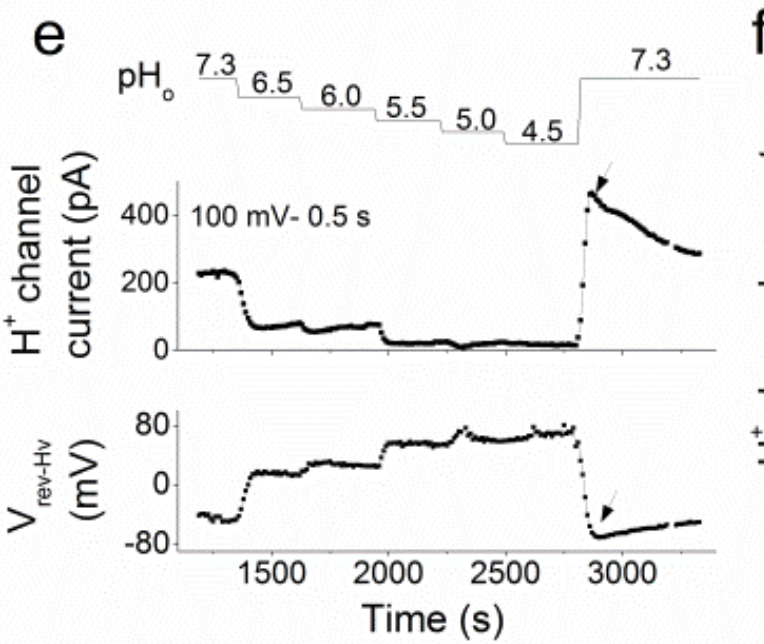

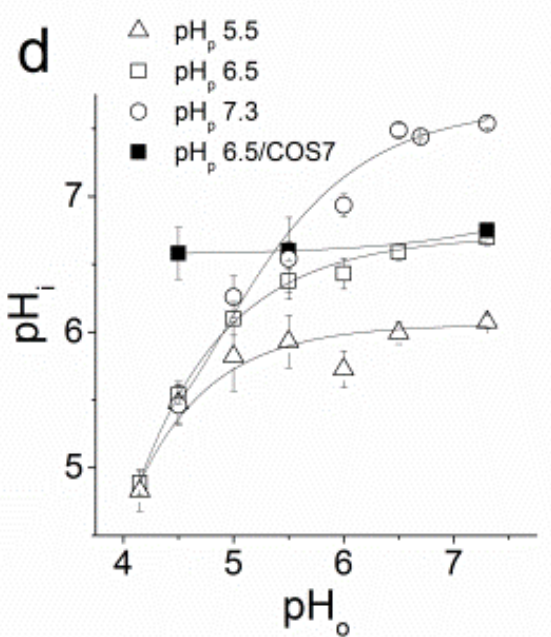

f

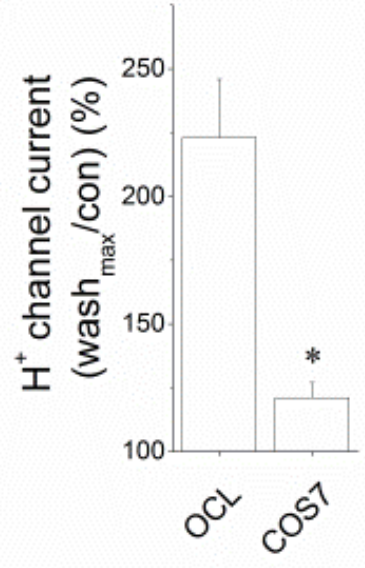


a-b, estimation of the reversal potentials for the $\mathrm{H}^{+}$channel $\left(\mathrm{V}_{\text {rev-Hv}}\right)$ with the tail current method. Tail currents were recorded at different voltages following $1 \mathrm{~s}$-long prepotentials $\left(80 \mathrm{mV}\right.$ for $\mathrm{pH}_{\mathrm{o}} 7.3$ and 120 $\mathrm{mV}$ for $\mathrm{pH}_{\mathrm{o}}$ 4.5) (a). After subtraction of leak currents at each voltages, the net tail currents were plotted against the voltages (b). The $\mathrm{V}_{\text {rev-Hv}}$ 's were indicated by arrows. The $\mathrm{pH}_{\mathrm{p}}$ was 6.5 . c, a plot of the $\mathrm{V}_{\text {rev-Hv }}$ values against the $\mathrm{pH}_{\mathrm{o}}(\mathrm{n}=3-25)$. The dotted line indicates the $E_{H}$ estimated from the $\mathrm{pH}_{\mathrm{o}}$ and $\mathrm{pH}_{\mathrm{p}}(6.5)$. d, the intracellular $\mathrm{pH}\left(\mathrm{pH}_{\mathrm{i}}\right)$ calculated from the $\mathrm{V}_{\text {rev-Hv }}$ values using the Nernst equation at each $\mathrm{pH}_{\mathrm{o}}$. $\mathrm{pH}_{\mathrm{p}}$ 's were 5.5 (triangles, $\mathrm{n}=2-42$ ), 6.5 (squares, $\mathrm{n}=3-25$ ) and 7.3 (circles, $2-42$ ). The $\mathrm{pH}_{\mathrm{i}}$ in $\mathrm{COS} 7$ cells transfected with a $\mathrm{H}^{+}$channel gene were indicated by closed squares $\left(\mathrm{pH}_{\mathrm{p}} 6.5\right)(\mathrm{n}=5-10)$. e, the changes in the $\mathrm{H}^{+}$channel current amplitudes (middle) and the $\mathrm{V}_{\text {rev-Hv }}$ 's (bottom) in an osteoclast $\left(\mathrm{pH}_{\mathrm{p}}\right.$ 6.5). The $\mathrm{pH}_{\mathrm{o}}$ was decreased stepwise, from 7.3 to 4.5 , and then was returned to 7.3. The current-amplitudes (upper) were measured at the end of the depolarization pulses $(100 \mathrm{mV}-0.5 \mathrm{~s})$ applied at a holding potential $(-40 \mathrm{mV})$ and the $\mathrm{V}_{\text {rev-Hv }}$ (lower) were estimated from the current amplitudes at two voltages, either 100 and $40 \mathrm{mV}$ or 40 and $-40 \mathrm{mV}$. f, overshoot of the $\mathrm{H}^{+}$channel currents after removal of acid $\left(\mathrm{pH}_{\mathrm{o}} 4.5\right)$ in osteoclasts and $\mathrm{COS} 7$ cells transfected with a $\mathrm{H}^{+}$channel gene. The currents (100 or $80 \mathrm{mV}$ for $0.5 \mathrm{~s}$ ) were measured under $\mathrm{pH}_{\mathrm{o}} / \mathrm{pH}_{\mathrm{p}}$ 7.3/6.5. The maximal current-densities after washing acids were expressed as percent of the controls. In c, $d$ and f, data are means \pm sem. 
Fig. 7 V-ATPase currents versus $\mathrm{H}^{+}$-leak currents

Fig. 7
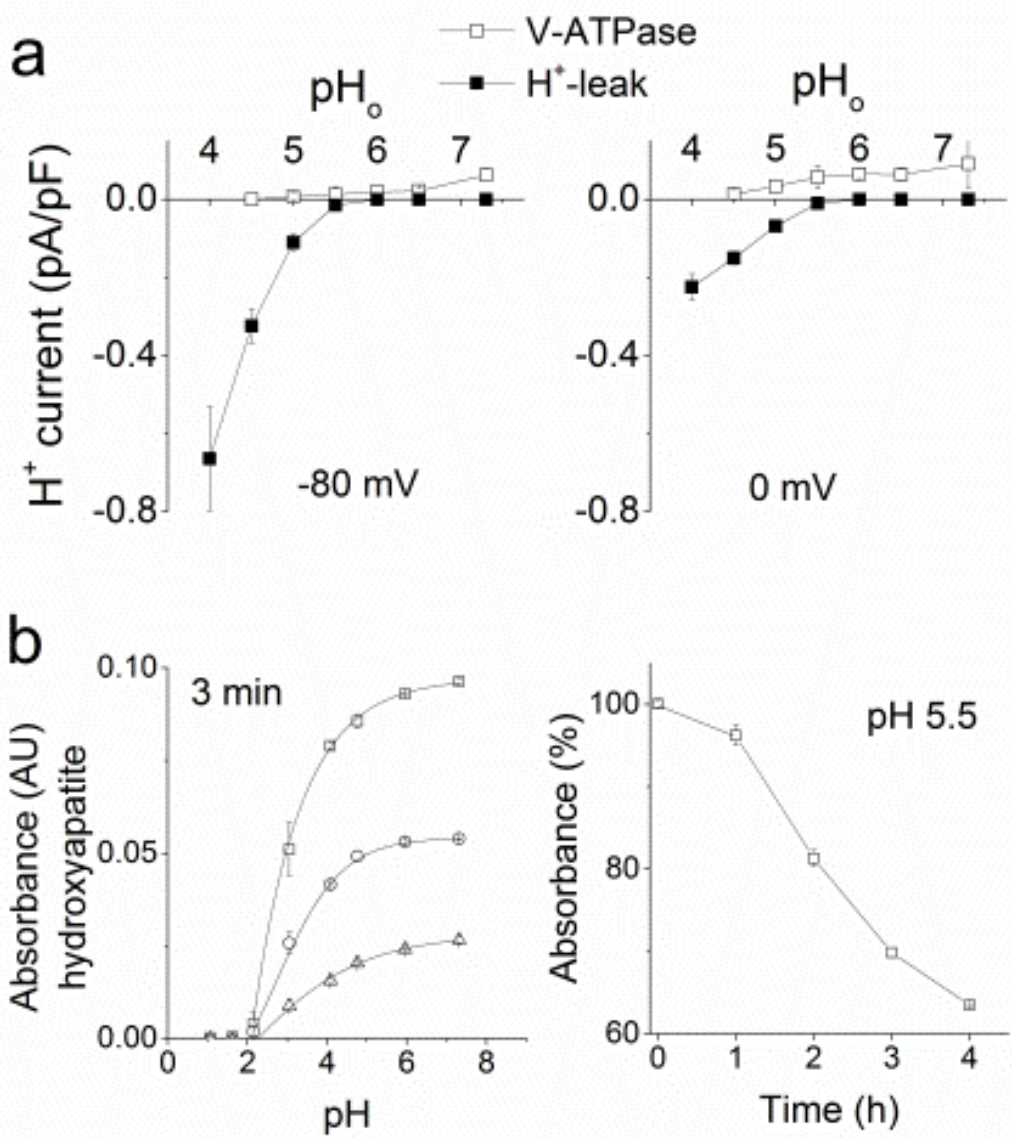

C

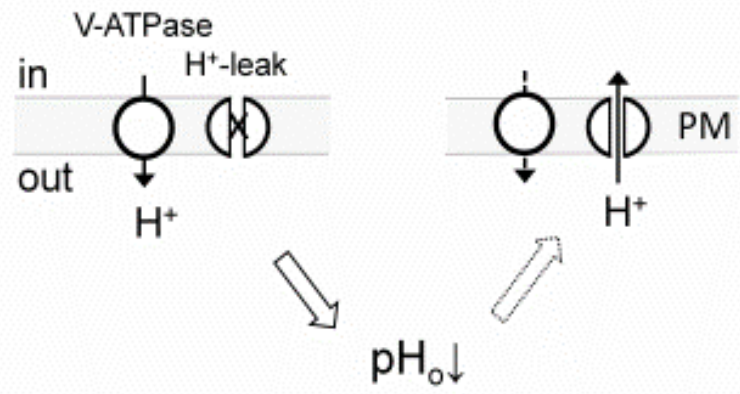


a, current-densities of outward $\mathrm{H}^{+}$currents through V-ATPases (open squares; $\mathrm{n}=3-19$ ) and the acid-inducible inward $\mathrm{H}^{+}$currents (closed squares; $\mathrm{n}=9-21$ ) recorded at $-80 \mathrm{mV}$ (left) and $0 \mathrm{mV}$ (right). The $\mathrm{pH}_{\mathrm{p}}$ was set at 6.5. V-ATPase currents were identified as bafilomycin-sensitive currents. b, dissolution of hydroxyapatites by acids. Left, absorbance of the Ringer solutions containing hydroxyapatite particles exposed to different $\mathrm{pHs}$ for $3 \min (\mathrm{n}=3)$ (in arbitrary units, AU). The suspensions contained hydoxypatate at 0.1 (triangles), 0.25 (circles) and 0.5 (squares) $\mathrm{mg} / \mathrm{ml}$. Right, the time course of dissolution of hydroxyapatite $(0.5 \mathrm{mg} / \mathrm{ml})$ at $\mathrm{pH} 5.5(\mathrm{n}=3)$. c, a simplistic cartoon of the proton fluxes at the plasma membrane of osteoclasts. The plasma membranes are rich in proton pumps, vacuolar $\mathrm{H}^{+}$-ATPases. Protons are secreted by V-ATPase, and then acidify the extracellular space. When the $\mathrm{pH}_{\mathrm{o}}$ is sufficiently decreased, the proton extrusion decreases and the $\mathrm{H}^{+}$-leak (acid-inducible $\mathrm{H}^{+}$ influx) pathway will be activated. In a and $b$, data are means \pm sem. 